This manuscript is a preprint. Despite having undergone peer-review, this manuscript has yet to be formally accepted in a journal. Subsequent versions of this manuscript may thus have different content. If accepted, the final version of this manuscript will be available via the 'Peer-reviewed Publication DOI' link on the right-hand side of this webpage. Please feel free to contact any of the authors directly or to comment on the manuscript using hypothes.is 


\title{
Rift-related magmatism influences petroleum systems development in the NE Irish
} Rockall Basin, offshore Ireland

\author{
Christopher A-L. Jackson \\ Craig Magee* \\ Carl Jacquemyn \\ Basins Research Group (BRG), Imperial College, Prince Consort Road, LONDON, SW7 \\ 2BP, England, $U K$

\begin{abstract}
*Present address: School of Earth and Environment, University of Leeds, Leeds, UK
\end{abstract} \\ email: c.jackson@imperial.ac.uk
}

\section{ABSTRACT}

Large volumes of hydrocarbons reside in volcanically influenced sedimentary basins. Despite having a good conceptual understanding of how magmatism impacts the petroleum system of such basins, we still lack detailed case studies documenting precisely how intrusive magmatism influences, for example, trap development and reservoir quality. Here we combine 3D seismic reflection, borehole, petrographic, and paleothermometric data to document the geology of borehole 5/22-1, NE Irish Rockall Basin, offshore western Ireland. This borehole (Errigal) tested a four-way dip closure that formed to accommodate emplacement of a Paleocene-toEocene igneous sill-complex during continental breakup in the North Atlantic. Two waterbearing turbidite sandstone-bearing intervals occur in the Upper Paleocene; the lowermost contains thin (c. $5 \mathrm{~m})$, quartzose-feldspathic sandstones of good reservoir quality, whereas the upper is dominated by poor-quality volcaniclastic sandstones. Paleothermometric data provide evidence for anomalously high temperatures in the Paleocene-to-Eocene succession, suggesting the poor reservoir quality within the target interval likely reflects sill-induced heating, fluid flow, and related diagenesis. The poor reservoir quality also likely reflects the primary composition of the reservoir, which is dominated by volcanic grains and related clays derived from an igneous rock-dominated, sediment source area. Errigal appeared to fail due to a lack of hydrocarbon charge; i.e. the low bulk permeability of the heavily intruded Cretaceous mudstone succession may have impeded vertical migration of sub-Cretaceous-sourced hydrocarbons into supra-Cretaceous reservoirs. Breakup-related magmatism did however drive formation of a large structural closure, with data from Errigal at least proving high-quality, Upper Paleocene deep-water reservoirs. Future exploration targets in the NE Irish Rockall Basin include: (i) 
stratigraphically trapped, Paleocene-to-Eocene deep-water sandstones that onlap the flanks of intrusion-induced forced folds; (ii) structurally trapped, intra-Cretaceous deep-water sandstones incorporated within intrusion-induced forced folds; and (iii) more conventional, Mesozoic fault-block traps underlying the heavily intruded Cretaceous succession (e.g. Dooish). Similar plays may exist on other continental margins influenced by break-up magmatism.

\section{INTRODUCTION}

Stretching and thinning of the lithosphere during continental breakup, or elevated mantle potential temperatures (Tp), drive melting of asthenospheric mantle (e.g. Jerram \& Widdowson, 2005; Allen \& Allen, 2013; Hole \& Millett, 2016). Magma formed during continental breakup may stall during its ascent to the Earth's surface, intruding the crust in the form of igneous sills and dykes. Because continental stretching precedes breakup, igneous intrusions are particularly common in some of the world's most prolific hydrocarbon provinces (e.g. offshore circumAtlantic, e.g. Smallwood and Maresh, 2002; Rohrman, 2007; Thomson \& Hutton, 2004; Archer et al., 2005; Magee et al., 2014; Schofield et al., 2017; NW Shelf of Australia, Reeckman and Mebberson, 1984; Magee et al., 2013a,b; McClay et al., 2013; Rohrman, 2015; Magee et al. 2017). Petroleum systems in these provinces are commonly assumed to be negatively impacted by breakup-related magmatism. For example, sill and dyke intrusion can cause: (i) physical compartmentalization of stratigraphy, leading to dissection of reservoirs, or separation of source and reservoir rocks by impermeable sills and dykes (e.g. Thomaz Filho et al., 2008; Senger et al., 2015; Eide et al., 2017; Grove et al., 2017); (ii) initiation of hydrothermal systems, with the local flow of anomalously hot fluids driving diagenesis at shallow depths and causing a reduction in reservoir quality (e.g. Grove et al., 2017); (iii) overmaturation of source rocks (e.g. Schutter, 2003; Rohrman, 2007; Holford et al., 2013; Schofield et al., 2018) (see also reviews by Schutter, 2003 and Senger et al., 2017); and (iv) operational (i.e. drilling) issues related to the pressure state of the intrusion and encasing rocks, or the high strength of the intrusions, both of which can lead to enhanced risk for equipment and personnel, and can lead to costly 'non-productive time' (e.g. Millet et al., 2016; Iyer et al., 2017; Mark et al., 2018). However, the discovery and production of hydrocarbons in association with igneous rocks demonstrate breakup-related magmatism may positively impact petroleum system development by: (i) causing the formation of structural and stratigraphic traps due to forced folding (e.g. Reeckmann and Mebberson, 1984; Smallwood and Maresh, 2002; Schutter, 2003; Wu et al., 2006; Rohrman, 2007; Magee et al., 2013a; Egbeni et al., 2014; Schmiedel et al., 2017; Mark et al., 2017; Schofield et al., 2018; Magee et al., 2019); (ii) creating a network of interconnected, potentially high-permeability intrusions that may act as either reservoirs (e.g. Reeckmann and 
Mebberson, 1984; Gu et al., 2002; Smallwood and Maresh, 2002; Schutter, 2003; Rohrman, 2007; Delpino \& Bermúdez, 2009; Farooqui et al., 2009; Wang et al., 2012; Witte et al., 2012; Egbeni et al., 2014; Bischoff et al., 2017), or as conduits that allow hydrocarbons to migrate from source rocks to reservoir rocks (e.g. Rateau et al., 2013; Rodriguez Monreal et al., 2009; Senger et al., 2015; Schofield et al., 2017; Mark et al., 2018); (iii) increasing the reservoir quality of encasing host rock (e.g. by dolomitization; see Jacquemyn et al., 2014); (iv) forming low-permeability seals (e.g. Schutter, 2003; Rodriguez Monreal et al., 2009; Wang et al., 2012); (iv) locally maturing otherwise regionally immature source rocks (e.g. Svensen et al., 2004; Wang et al., 2012; Holford et al., 2013; Aarnes et al., 2015; Iyer et al., 2017; Muirhead et al., 2017; Senger et al., 2017); and (v) acting a seals to hydrocarbons trapped in more conventional reservoirs (e.g. Schutter, 2003; Wu et al., 2006; Thomaz Filho et al., 2008; Holford et al., 2013). Our understanding of how magmatism impacts petroleum systems development in volcanic basins has grown in recent years, yet we still lack detailed case studies documenting the precise influence intrusive magmatism has on, for example, trap development and reservoir quality (see reviews by Schutter, 2003, Rohrman, 2007, and Senger et al., 2017). Even with a relatively advanced conceptual framework within which to risk prospects and devise field development plans, hydrocarbon exploration and development in volcanic basins remains challenging (Mark et al., 2017; Schofield et al., 2018).

To help improve our understanding of how breakup-related magmatism impacts petroleum systems development along continental margins, we provide a detailed post-well analysis of exploration borehole 5/22-1, which tested the Errigal prospect, NE Irish Rockall Basin (PEL 6/97), offshore western Ireland (Fig. 1). This borehole was drilled by Enterprise Energy Ireland Ltd and partners in 2001, targeting a large $\left(c .77 \mathrm{~km}^{2}\right.$; revised to $52 \mathrm{~km}^{2}$ postdrilling; see Supplementary Item 1) dome (i.e. four-way dip closure) situated c. $42 \mathrm{~km} \mathrm{NNW}$ of the Dooish discovery (12/2-1), which was drilled in 2003 and represents the first commercial hydrocarbon discovery in the NE Irish Rockall Basin (Figs 1 and 2). Borehole 5/22-1 took 26 days to drill to a total depth of $4070 \mathrm{~m}$, in water depths $>1500 \mathrm{~m}$. The primary and secondary objectives were Upper and lower Paleocene deep-water sandstone, respectively, sealed by latest Paleocene and Eocene mudstone (Fig. 1C). The prognosed trap and reservoir-seal pairs are underlain by an extensive, breakup-related (i.e. earliest Paleocene-to-early Eocene), igneous sill-complex primarily intruded into Cretaceous mudstone (Figs 2 and 3) (Magee et al., 2014). Oil was predicted to be the main hydrocarbon phase, sourced from Lower Jurassic (intra-rift) or Upper Jurassic (syn-rift) marine mudstone. The well reached Late Cretaceous rocks (Figs 1C and 2) and, despite penetrating a sandstone-bearing Eocene and upper Paleocene sequence, was plugged and abandoned as a dry hole, with only very minor traces of hydrocarbons being recorded in the target interval. 
Although the failure of Errigal seemingly cast doubt on the prospectivity of this play type in at least this particular part of the NE Irish Rockall Basin, data acquired during drilling

113 provide an excellent opportunity to assess the role breakup magmatism had on petroleum 114 systems development in this and possibly other volcanically influenced basins. We begin by

115 briefly summarizing the tectono-magmatic and petroleum systems framework of the NE Irish

116 Rockall Basin, before using 3D seismic reflection and borehole data to constrain the structural, 117 stratigraphic, and magmatic context of Errigal. We place particular emphasis on the origin and 118 timing of the trap, and how this relates to breakup magmatism. We then use a range of 119 predominantly pre-2004, now-released data, generously provided by the Department of 120 Communications, Energy and Natural Resources (Petroleum Affairs Division), Ireland to: (i) 121 describe and interpret spatial and temporal changes in the thickness and quality of the main 122 Paleocene reservoir target (e.g. via final well reports, petrographic analysis); and (ii) constrain 123 the paleothermometric evolution via fluid inclusion microthermometry (FIM), vitrinite 124 reflectance (VR) and apatite fission track analysis (AFTA) data from the basin, with a view as 125 to how this might relate to the inferred magmatic events and observed reservoir quality. In 126 addition to improving our understanding of petroleum systems development along the deep127 water margin of western Ireland and the UK (e.g. the Faroe-Shetland Basin and UK Rockall 128 Basin; sensu Schofield et al., 2018), the results of our study can also help us better understand 129 the challenges associated with similar prospects identified in other volcanically influenced 130 basins worldwide.

\section{GEOLOGICAL SETTING AND PETROLEUM SYSTEM ELEMENTS}

The Rockall Basin is located along the NE Atlantic continental margin (Fig. 1). It is one of several deep-water (i.e. water depth of up to $1800 \mathrm{~m}$ ) rifts that formed during initial opening of the North Atlantic (e.g. Doré et al. 1999; Naylor \& Shannon 2005; Hansen et al. 2009). In the NE Irish Rockall Basin the earliest phase of breakup-related extension occurred in the PermoTriassic ('syn-rift I' of Magee et al., 2014; Figs 1C and 2), with a second phase occurring in the Middle-to-Late Jurassic ('syn-rift II' of Magee et al., 2014; Figs 1C and 2) (e.g. Doré et al. 1999; Naylor \& Shannon 2005; Tyrell et al. 2010). Marine mudstone source rocks may occur in the Lower (Lias equivalent) and Upper (Kimmeridge Clay Formation equivalent) Jurassic successions, although this remains speculative due to a lack of deep borehole data (e.g. Doré et al. 1999; Tyrell et al. 2010; see also discussion by Schofield et al., 2018 on the UK Rockall Basin).

Northwards propagation of North Atlantic seafloor spreading during the late Early 146 Cretaceous (Aptian-to-Albian) led to NW-SE-oriented extension and a third phase of rifting in the Rockall Basin (Doré et al. 1999). A deep marine, mudstone-dominated succession was 
148 deposited within the deepening rift during this period of Early Cretaceous stretching ('syn-rift

149 III' of Magee et al., 2014; Figs 1C and 2) (Naylor \& Shannon 2005). Early Cretaceous extension

150 was superseded by Late Cretaceous-to-Paleogene post-rift thermal subsidence. During the Late

151 Paleocene and Eocene, deposition of deep-marine mudstone was intermittently interrupted by

152 the deposition of deep-water sandstone derived from a volcanic terrain emplaced during the

153 immediately preceding (and in places broadly synchronous) period of breakup-related

154 magmatism (see also Naylor \& Shannon 2005; Haughton et al. 2005).

155 Paleocene deep-water sandstone and Eocene mudstone represented the prognosed 156 reservoir and seal, respectively, for the Errigal prospect. Lower and Upper Jurassic marine 157 mudstone, in addition to underlying Carboniferous coals, represent potential source rocks. The 158 Dooish discovery (estimated to contain recoverable volumes of c. 256 bcf and c. 17 mmbbls $15945^{\circ}$ API condensate) contains a Mesozoic (Triassic-to-Middle-Jurassic), marginal marine 160 sandstone reservoir located in a rift-related fault block, demonstrating the presence of a working 161 petroleum system within the NE Irish Rockall Basin (Fig. 1C and 2).

162

\section{BREAKUP RELATED MAGMATISM AND ASSOCIATED DEFORMATION}

Late Cretaceous-to-Early Eocene, breakup-related magmatism is common along the NE Atlantic Margin, manifesting as flood basalt lava flows, sill-complexes and volcanic centres (North Atlantic Igneous Province; Fig. 1A). The products of this magmatism have been identified and described using seismic reflection and borehole data from the UK (Thomson \& Hutton, 2004; Archer et al. 2005) and NE Irish Rockall basins (Fernandes, 2011; Magee et al., 2014). Igneous intrusions, in particular sills, are common in the NE Irish Rockall Basin, being expressed in seismic reflection data as very high amplitude, typically strata-discordant reflections (Fig. 2) (Magee et al., 2014). The presence of intrusive igneous material in the NE Irish Rockall Basin is confirmed by well 12/2-1, which penetrates a $c .14 \mathrm{~m}$ thick dolerite sill in upper Paleocene mudstones overlying the Dooish discovery (e.g. Figs 1C and 4).

An extensive network of large, interconnected, saucer-shaped and inclined sills, which individually are up to $12.4 \mathrm{~km}$ long and cross-cut $1.8 \mathrm{~km}$ of stratigraphy, are developed north of Dooish (Fig. 2) (Magee et al., 2014). These intrusions are most densely stacked directly

178 beneath the dome drilled by 5/22-1 and are largely hosted within Upper Cretaceous mudstone,

179 although a few extend upwards into the reservoir-bearing Paleocene succession (Fig. 5; cf. the 180 Rockall (e.g. Schofield et al., 2018) and Faroe-Shetland (e.g. Mark et al., 2017) basins). Based 181 on: (i) the fact that the sills are most densely stacked below the dome apex; and (ii) the observation that the Paleocene to Lower Eocene succession onlaps onto and thins across the 183 dome (Figs 2 and 5), Magee et al. (2014) argue the dome (forced fold) formed to accommodate 
184 incremental emplacement of magma over a $c a$. $15 \mathrm{Myr}$ period earliest Paleocene-to-early

185 Eocene (Danian-to-Ypresian).

\section{DATASET}

Our dataset comprises: (i) digital seismic reflection and borehole data, much of which was presented by Magee et al. (2014) in their study of the tectono-magmatic history of the NE Irish Rockall Basin; and (ii) 'analogue' data derived from now-released reports detailing previously confidential analyses undertaken immediately after drilling of 5/22-1 (Errigal) in 2001 and 12/2-1 (Dooish) in 2003 (see Supplemental Items 1-6, which are available upon request from the Department of Communications, Climate Action \& Environment (Petroleum Affairs Division), Ireland via https://www.dccae.gov.ie/en-ie/natural-resources/topics/Oil-GasExploration-Production/data/Pages/Data.aspx).

\section{Seismic reflection data}

The seismic dataset comprises a zero-phase, time-migrated, 3D seismic reflection survey that covers $2400 \mathrm{~km}^{2}$. Inline (N-S) and crossline (E-W) spacing is $12.5 \mathrm{~m}$ (Fig. 1B). These data are displayed with a normal polarity, whereby a downward increase and decrease in acoustic impedance corresponds to a positive (red) and negative (blue) reflection, respectively (Fig. 2). We mapped four horizons: (i) Top Hauterivian (KH) (intra-syn rift III); (ii) Top Cretaceous (K) (near base reservoir); (iii) Top Paleocene (P) (near top reservoir); and (iv) Top Lower Eocene (E) (intra-post rift). Where data quality allows, we locally define and map an additional seismic horizon that corresponds to the intra-Cenomanian (KC) and likely demarcates the boundary between syn-rift III and younger post-rift rocks (Fig. 2). and $4000 \mathrm{~m} \mathrm{~s}^{-1}$ (below K) were calculated from borehole data. Given that the dominant seismic frequency is $c .25 \mathrm{~Hz}$ in the stratigraphic interval of interest, interval velocities of 3220-4000 $\mathrm{m} \mathrm{s}^{-1}$ suggest that the vertical resolution of the seismic data ranges from $c$. $32-40 \mathrm{~m}$ for the host

\section{Borehole and petrophysical data}

We use data from two boreholes (5/22-1; Errigal, and 12/2-1; Dooish) to constrain the age and lithology of the seismically mapped stratigraphic units (Figs 2 and 5). Both boreholes contain

219 a full suite of well-log data, including gamma-ray (GR), density (RHOB), and velocity (DT)

220 logs. Composite logs (Supplemental items 2 and 6) and cuttings data (see information provided 
in Supplemental items 1, 2 and 6) were available for 5/22-1 and 12/2-1; a final well report was also available for 5/22-1 (Supplemental Item 1).

As documented in the final well report for 5/22-1, Volume-of-clay ( $\mathrm{Vcl}$ ) determination was difficult in the Upper Palaeocene interval of interest. A GR-based approach yielded results that were not consistent with cuttings and sidewall core descriptions, or other log responses such as spontaneous potential (SP). More consistent results were gained by using the separation in the RHOB and DT logs, or from the SP measurements; the former was eventually used to constrain $\mathrm{Vcl}$ given it had a higher vertical resolution (i.e. sampling interval).

Porosity was determined from the RHOB log using an equation that has been modified to account for the high non-net clay component:

$$
\Phi=\frac{(\text { RHOma }- \text { RHOlog })-V c l(\text { RHOma }- \text { RHOcl })}{\text { RHOma }- \text { RHOfl }}
$$

where RHOma=rock density in $\mathrm{g} \mathrm{cm}^{3}$, RHOlog $=\mathrm{Y}$, RHOcl=Z, and RHOfl=A (see Supplementary Item 1). Note that core grain density was not available for the Paleocene interval of interest, thus a value of $2.67 \mathrm{~g} \mathrm{~cm}^{3}$ was used based on core data from analogues rock types penetrated in boreholes west of Shetland.

\section{Petrographic data}

Thin section descriptions (Fig. 6), point-counted petrological descriptions (Table 1 in Supplementary Item 1) and SEM analyses (raw data not available) were undertaken for 13 sidewall core samples; 11 of these samples were also studied by whole rock X-ray diffraction (Table 2 in Supplementary Item 1). X-ray diffraction samples for the Upper Paleocene interval of interest were taken from between 3470-3925 m (white and greyscale dots in Fig. 4).

\section{Paleothermometric data}

Paleothermometric data are provided in the form of several reports documenting the methods and analyses undertaken by the operator company and contractors soon after completion of 5/22-1 (Errigal) in 2001. The paleothermometric analysis presented here includes the results of FIM (Supplementary Item 3), VR and AFTA analysis (Supplementary Item 4).

\section{PALEOCENE RESERVOIR DISTRIBUTION, QUALITY AND PROVENANCE}


256 We here describe and interpret the distribution and quality, and infer the possible provenance

257 of, the upper Paleocene deep-water sandstones penetrated in 5/22-1 (Errigal) and 12/2-1

258 (Dooish) (Fig. 4; see also Supplementary items 1-3).

\section{5/22-1 (Errigal)}

5/22-1 penetrated two deep-water turbidite sandstone-bearing intervals (upper Paleocene 1 and

2) in the primary, upper Paleocene objective; no sandstones were developed in the secondary, lower Paleocene objective (Fig. 4; see also Supplementary items 1 and 2).

The upper sandstone-bearing interval (3505-3619 m; labelled 'Pal. 1' in Fig. 4) is $c$. $114 \mathrm{~m}$ thick and contains 1-4 m thick beds of generally well-sorted, subangular-to-subrounded, very fine-to-locally medium-grained volcaniclastic sandstones that contain "mafic" grains (Fig. 6A and B; see also Supplementary items 1 and 2). Petrophysical analysis of the upper interval, using a volume-of-clay ( $\mathrm{Vcl}$ ) cut-off of $50 \%$ (i.e. $\mathrm{Vcl}>50 \%$ is non-net sand) and a $10 \%$ porosity cut-off for net-reservoir, indicates that the net reservoir content $(1.4 \mathrm{~m})$ and resulting net-togross $(\mathrm{N}: \mathrm{G})$ of the upper interval is very low $(<1 \%)$ (Supplementary Items 1 and 2; see also Fig. 4).

Thin section (Fig. 6B) and SEM analysis (Supplementary Item 1) reveals that chlorite and chlorite smectite ( $46 \%$ of the bulk rock volume), smectite and zeolites (analcime; $18 \%$ of the bulk rock volume) are the main cement phases, filling pores and clogging pore throats. Pyrite, gypsum and small amounts of carbonate and authigenic feldspar are also observed, in addition to weathered volcanic glass fragments and tuffaceous material. Authigenic quartz is lacking, reflecting the lack of primary detrital quartz or inhibition of quartz precipitation due to the presence of chlorite (Supplementary items 1 and 2) (e.g. Berger et al., 2009). Despite locally having a relatively high porosity $(21 \%)$, reservoir quality in the upper interval is rather poor, with porosity being dominated by intercrystalline and grain dissolution-related microporosity (Supplementary Item 1). We note that these somewhat surprisingly high porosity values may be erroneous, given they were calculated using neutron logs that would record water bound to the (hydrous) clay minerals, and not necessarily water within the pore spaces (e.g. Broglia \& Ellis, 1990). As such, the porosity of this volcaniclastic sandstone in Paleocene 1 could be substantially lower.

The lower sandstone-bearing interval (3619-3930 m; labelled 'Pal. 2' in Fig. 4) is $c$. $311 \mathrm{~m}$ thick and contains scattered, generally thinner ( $<4 \mathrm{~m}$ and more commonly 1-2 m thick), volcaniclastic sandstones, of similar composition to the upper interval (see also Supplementary items 1 and 2). However, towards its base, this interval contains two c. $5 \mathrm{~m}$ thick, quartzosefeldspathic sandstones (3916-3926 m; Fig. 4). These sandstones are fine-to-medium-grained and moderately well-sorted, with individual grains being subangular. Note that, although 
petrographically distinct from overlying, volcaniclastic sandstones, the quartzose-feldspathic sandstones were originally assigned to 'Pal. 2' in the post-drilling reports; for consistency we retain this nomenclature here (Fig. 4; see also Supplementary Item 1).

Thin-section (Fig. 6C) and SEM (Supplementary Item 1) analysis indicate that the quartzose-feldspathic sandstones have distinctly different cement phases and porosity systems to the immediately overlying sandstones or those within upper Paleocene 1. First, they lack pore-filling and pore throat-bridging chlorite, chlorite smectite and zeolite, instead containing relatively limited amounts of illite and kaolinite, in addition to some carbonate cements (Fig. 6C); volcanic glass fragments are also absent. Second, well-connected interparticle macroporosity, instead of poorly developed intercrystalline and grain dissolution-related microporosity, is present in these sandstones (cf. Figs 6B and C; see also Supplementary Item 1). Petrophysical analysis of the entire lower interval, using the same criteria as the upper interval, indicates that the net sand content $(8.1 \mathrm{~m}$ ) and $\mathrm{N}: \mathrm{G}$ is very low (c. 3\%) (see Fig. 4), although the porosity of the basal quartzose-feldspathic sandstones is generally quite good (up to $16 \%$ ) (Supplementary Item 1 ).

\section{2/2-1 (Dooish)}

Because the Triassic and Jurassic succession was the target of well 12/2-1, only a completion $\log$ is available for the Paleocene succession (Supplementary Item 5). These data indicate that the $>500 \mathrm{~m}$ thick ipper Paleocene succession is mudstone-dominated; however, in its lower $c$. $150 \mathrm{~m}$, it contains several 1.5-12 m thick, volcaniclastic sandstone beds in an overall silty, relatively low N:G interval (c. 20\%) (Fig. 4; see also Supplementary Item 5). Texturally, these sandstones are fine-to-coarse-grained, angular to subrounded, and very well-sorted. Compositionally these sandstones are composed of quartz, volcanic lithics and volcanic glass (Supplementary Item 5), similar to the volcanic sandstone described in the upper part of 5/221 (Pal. 1). In the upper part of the upper Paleocene succession, a few 1-3 m thick beds of medium-to-coarse-grained, very well-sorted, subangular-to-subrounded sandstones occur (Fig. 4; see also Supplementary Item 5). These sandstones are compositionally very different to those encountered lower in the succession, being quartz-rich and lacking volcanic lithics or volcanic glass. These upper sandstones are similar to the quartzose-feldspathic beds present near the base of the upper Paleocene succession in 5/22-1 (Pal. 2).

\section{Interpretation and comparison of 5/22-1 (Errigal) and 12/2-1 (Dooish)} volcanic grains within the upper Paleocene volcaniclastic sandstones penetrated in 5/22-1 
330 (Errigal) (Pal. 1) were sourced from relatively distal volcanic terrains forming part of the British 331 and Irish Paleogene Igneous Province. Onshore elements of this province lay to the E (i.e. 332 Northern Ireland) and NE (i.e. Scotland) of the NE Irish Rockall Basin (Fig. 1A). The abundant 333 volcanic glass, which is indicative of magma-water interaction (e.g. Friedman \& Long, 1984), 334 and tuffaceous material may have been derived from relatively proximal, offshore volcanic 335 sources, such as submarine volcanoes or hydrothermal vents genetically related to the 336 underlying sill-complex. However, the fact the glass is weathered argues against this 337 interpretation. The clay-rich nature of these sandstones likely reflects diagenetic degradation of 338 the mafic volcanic grains forming the bulk of the depositional unit (cf. Primmer et al, 1997).

339 In contrast to the volcanic terrain-derived sandstones, the quartzose-feldspathic 340 sandstones at the base of upper Paleocene (Pal. 2) were more likely derived from a sedimentary 341 or meta-sedimentary source area. We can interpret the compositional differences between the 342 upper (Pal. 1) and lower (Pal. 2) sandstones in one of two ways: (i) the sandstones were sourced 343 from different locations; i.e. the majority of the sandstones were derived from a regionally 344 extensive, volcanic source area (Pal. 1), whereas the oldest, quartzose-feldspathic sandstones 345 at the base of Pal. 2 were derived from a more local, sedimentary or meta-sedimentary source 346 area; or (ii) the amount of contemporaneous volcanism changed through time; i.e. the basal, 347 quartzose-feldspathic sandstones near the base of Pal. 2 were deposited prior to emplacement 348 of the widespread volcanic terrain that now dominates the northern basin margin, whereas 349 younger sandstones (i.e. most of Pal. 2 and all of Pal. 1) were deposited later, either synchronous 350 with and/or after widespread volcanism.

351 The upper Paleocene succession encountered in 12/2-1 (Dooish) is markedly different 352 to that in 5/22-1. First, quartzose-feldspathic sandstones, broadly similar in composition to 353 those near the base of 5/22-1, are instead found near the top of the upper Paleocene succession 354 in 12/2-1. Second, volcaniclastic sandstones are also present in 12/2-1, but they occur near the 355 base rather than near the top of the upper Paleocene succession (cf. 5/22-1; Fig. 4). The reason 356 for this variability is unclear, although it might point to temporal and spatial changes in the 357 provenance of the Paleocene deep-water sandstones, with time-equivalent sands being sourced 358 from either a meta-sedimentary or a volcanic source area (see discussion above). However, due 359 to a lack of biostratigraphic data we are unable to directly correlate upper Paleocene sandstones 360 between 5/22-1 and 12/2-1, and because the sandstones are relatively thin $(<5 \mathrm{~m})$ we are unable 361 to directly map them in seismic reflection data. Nonetheless, seismic data clearly indicate that 362 the entire Paleocene interval thins across the Errigal forced fold (see Magee et al., 2014), 363 suggesting the structure grew during this time and may have influenced reservoir deposition 364 (see discussion below) (Smallwood \& Maresh, 2002; Egbeni et al., 2014). 
368 Only traces of hydrocarbons are reported in 5/22-1, with the main upper Paleocene sandstone-

369 bearing intervals being water-bearing (Supplementary items 1 and 6). However, dead oil was

370 noted in cuttings from intervening siltstones, which, along with the nearby Dooish discovery,

371 clearly indicates the presence of a working petroleum system in the NE Irish Rockall Basin.

372 These observations imply that source rocks are present in the basin, and that the thermal history

373 of the basin led to maturation of these source rocks (see below). Given the basin's tectono-

374 stratigraphic development, its thermal history likely reflects: (i) regional (i.e. basin-scale)

375 heating due to rifting; (ii) regional cooling due to post-rift, intra-plate shortening and uplift,

376 likely related to plate break-up and associated ridge push (e.g. Tuitt et al., 2010), or magmatic

377 underplating (e.g. Brodie and White, 1994); and (iii) local heating driven by the emplacement

378 of igneous intrusions, some of which extend upwards into the reservoir-bearing Paleocene

379 succession (e.g. the sill located only c. $1.5 \mathrm{~km}$ to the NW of 5/22-1 in Fig. 2). It is likely that

380 rift-related heating drove source rock maturation of Carboniferous coals for Dooish, which,

381 although overlain by a single, $15 \mathrm{~m}$ thick intrusion, does not appear to be spatially related to a

382 very large intrusion complex, unlike Errigal (Fig. 2).

383 A key question is whether local, intrusion-induced heating was responsible for the poor 384 reservoir quality observed within the upper Paleocene succession in Errigal. More specifically, 385 did contact metamorphism and/or intrusion-induced fluid circulation result in the degradation 386 of volcanic grain assemblages, the clogging of pore space, blocking of pore throats and 387 therefore the overall poor reservoir quality? To try and answer this question we examine FIM, 388 VR and AFTA data obtained from sidewall core samples from the reservoir-bearing, Upper 389 Paleocene succession. These data could help us determine whether the reservoir-bearing 390 interval experienced elevated temperatures during burial in response to the emplacement of sills 391 in Upper Cretaceous-to-Paleocene mudstones (see methodology outlined in Supplementary 392 items 3 and 4; data from these Supplementary items are synthesized in Figs 7-9 and shown in 393 Tables 1 and 2).

397 Results. Microthermometry and fluorescence petrography was performed on fluid inclusions 398 by the operator on samples from 12 sidewall cores taken from the Paleocene succession in 5/223991 (Fig. 7; see also Supplementary Item 3). Primary aqueous fluid inclusions were found in 400 analcime cement and authigenic quartz. The majority (91\%; i.e. 31 of 34) of analcime-hosted 401 primary inclusions were monophase, indicating formation below $60^{\circ} \mathrm{C}$. However, some two402 phase inclusions ( $9 \%$; i.e. 3 of 34 ) are present that exhibit higher homogenisation temperatures 403 of $108^{\circ} \mathrm{C}$ to $119^{\circ} \mathrm{C}$. (Fig. 7). Homogenisation temperatures recorded in primary inclusions of 
quartz overgrowths in the lowermost sandstones (3916 and $3925 \mathrm{~m}$; Pal. 2) range from $66^{\circ} \mathrm{C}$ to $82^{\circ} \mathrm{C}$. Salinity of all primary inclusions is brackish $(1.1-2.3 \% \mathrm{NaCl}$ equivalent) to low $(0.1-$ $0.5 \% \mathrm{NaCl}$ equivalent) for analcime and authigenic quartz, respectively.

One healed microfracture in a quartz grain contained petroleum- and associated waterbearing fluid inclusions (3490 m; Figs 4 and 7). These inclusions record fluid precipitation and trapping at higher temperatures $\left(120-125^{\circ} \mathrm{C}\right)$ and salinities $(3.4 \% \mathrm{NaCl}$ equivalent) than that observed in analcime and the authigenic quartz (Fig. 7; see also Supplementary Item 3).

Interpretation. Given that: (i) the present bottom hole temperature is $76^{\circ} \mathrm{C}$; and (ii) based on the assumption that the rocks are presently at or near their maximum burial depth, most homogenisation temperatures indicate fluid trapping and/or resetting at temperatures consistent with their present burial depth. However, some samples contain evidence for elevated homogenisation temperatures, possibly related to a very brief period of localised hot fluid flow (see Supplementary items 3 and 4; see also discussion below). The detrital grain-hosted quartz microfracture at $3490 \mathrm{~m}$ also contains evidence for elevated paleotemperatures. However, the related fluids are considerably more saline than that encountered in other primary inclusions, suggesting they may not have been trapped in situ, but were rather 'inherited' from the grain source area. As such, this sample may not record the burial-related history of the succession penetrated by $5 / 22-1)$.

\section{Vitrinite Reflectance (VR)}

Results. VR was analysed for 26 cutting samples in 5/22-1. As discussed in Supplementary item 4, confidence levels for individual determinations are moderate to low. However, no significant differences exist between the most and least reliable results. Despite low confidence levels and scatter around the overall trend (see below), the results arising from the VR and AFTA analysis are at least consistent, suggesting the former provides a reliable assessment of maturity levels and the basin thermal history. VR values vary from $0.27 \%$ to $0.48 \%$, corresponding to temperatures of $<50 \mathrm{C}$ to $80^{\circ} \mathrm{C}$ (Fig. 8 and Table 1). Temperatures broadly increase with depth. The maturity of all samples, except for the second shallowest sample at $0.27 \%$, are higher than the 'baseline', burial-related heating only, thermal history (red line in Fig. 8; see also Supplementary item 4). In detail, anomalously high maturity levels are particularly apparent in the $500 \mathrm{~m}$ thick, upper Paleocene-to-middle Eocene interval (between c. 3100-3600 m) that contains the poor-quality, volcaniclastic reservoirs (Pal. 1) (Fig. 8; see also Fig. 4).

Interpretation. Temperatures broadly increase with depth; this is consistent overall with burialrelated heating (Fig. 8). However, the anomalously high maturity levels in the upper Paleocene- 
to-middle Eocene interval between c. $3100-3600 \mathrm{~m}$ indicate a temperature differential of on

442 average, $20^{\circ} \mathrm{C}$. Elevated temperatures may record a localized heating effect resulting from the

443 passage of hot fluids (see below), an interpretation that at least broadly supports that derived from Fluid Inclusion Microthermometry and fluorescence petrography (see above).

\section{Apatite Fission Track Analysis (AFTA)}

Results. AFTA was performed on seven cutting samples in 5/22-1 (Supplementary item 4). In general, the high apatite yields and analysis are deemed to be of very high quality, providing reliable constraints on thermal history (Supplementary Item 4). However, apatites from all samples contain a large proportion of fission tracks formed prior to deposition, an observation that can impact the thermal history interpretation. One of the samples collected between 3575 and $3800 \mathrm{~m}$ had a mean track length of $1.4 \mu \mathrm{m}$ shorter than predicted by the 'baseline' burialrelated heating only thermal history, whereas five out of the remaining seven samples had lengths $\sim 1.4-2 \mu \mathrm{m}$ shorter than predicted. For one sample only two track lengths were measured, and so cannot be used to assess its thermal history.

Interpretation. The occurrence of track lengths shorter than predicted by the 'baseline' burialrelated heating only thermal history can be explained by either an inherited signal from the sediment source terrain, elevated paleotemperatures after deposition, or a combination of both. If we interpret this signal was not inherited from the source terrain, these data suggest the onset of cooling of the studied samples from paleotemperatures $15-45^{\circ} \mathrm{C}$ above the present, sometime between 40 and $10 \mathrm{Ma}$. This interpretation would be consistent with the results arising from the FIM and VR analyses presented above, which suggest a localised heating event in the Paleocene succession, perhaps related to the passage of hot fluids. We also note that the oldest age for the onset of cooling (c. $40 \mathrm{Ma}$; middle Eocene) post-dates the latest period of magmatism constrained by Magee et al. (2014).

\section{DISCUSSION}

471 No significant oil shows were discovered in 5/22-1, although traces were reported at $3420 \mathrm{~m}$

472 (lower Eocene), $3690 \mathrm{~m}$ (upper Paleocene) and $3900 \mathrm{~m}$ (lower Paleocene) (Supplementary Item

473 6). Headspace and cuttings gas data provide only weak evidence for relatively dry, thermogenic 474 gas in the Cretaceous-to-Paleocene succession (Supplementary Item 6). We here critically re475 evaluate why 5/22-1 failed, and examine the broader role breakup-related magmatism may play 476 in controlling the future prospectivity of the NE Irish Rockall Basin and other magmatically 477 influenced basins. 


\section{Why did Errigal fail?}

Source presence, maturation, and migration. The Dooish gas discovery (12/2-1) provides evidence for a working source rock in the NE Irish Rockall Basin. However, the type (e.g. marine, non-marine, or mixed; Type I-III), richness (e.g. TOC), and distribution of, and the stratigraphic level at which this source rock occurs (e.g. Carboniferous, Lower or Upper Jurassic) remains highly uncertain. VR data from 5/22-1 indicate Cretaceous-to-Paleocene mudstones are under mature, even for oil (i.e. they have VR values substantially $<0.5 \%$; see Fig. 8), suggesting they were not the source for the gas in Dooish or the gas encountered in the Cretaceous-to-Paleocene succession in 5/22-1. Thus, despite being heavily intruded, a process which could locally mature otherwise regionally immature source rocks (e.g. Schutter, 2003; Rodriguez Monreal et al., 2009; Aarnes et al., 2015; Muirhead et al., 2017), these mudstones appear unable to generate appreciable volumes of hydrocarbons.

Given there is good evidence for the presence of mature source rock in the NE Irish Rockall Basin, it is thus important to consider whether migration was reason Errigal failed. Errigal is underlain by extensive sill-complex (Fig. 2). In addition to our 82 seismically resolvable and mapped sills, it is likely that additional, sub-seismic sills, and possibly subvertical (and thus poorly imaged) dykes are present. For example, based on seismic reflection and borehole data from the Faroe-Shetland Basin, Schofield et al. (2015) argue that $88 \%$ of sills may be sub-seismic (i.e. $<40 \mathrm{~m}$ thick), leading to a drastic underestimation of the total volume of sill-hosted igneous material. In the NE Irish Rockall Basin we cannot constrain the permeability of individual sills or their host rock due to a lack of deep borehole data. We therefore provide two hypotheses for the permeability structure of interval separating source and reservoir rocks. First, the intrusions could be permeable due to the presence of coolinginduced fractures (e.g. Rateau et al., 2013; Rodriguez Monreal et al., 2009; Senger et al., 2015;

504 Schofield et al., 2017; Mark et al., 2018). The host rock could also be permeable due to the 505 development of burial-related fracture networks, which may have been enhanced by 506 overpressure development and hydrofracture development (e.g. Cosgrove, 2004; 507 Gudmundsson, 2011). In this case, any gas (or oil) generated by the source rock could have 508 migrated relatively freely up into the shallower reservoirs. An alternative interpretation is that 509 the bulk permeability of the sub-reservoir sill-complex is relatively low (i.e. the sills and their 510 host rock are only weakly fractured). In this case, any hydrocarbons expelled from pre511 Cretaceous source rocks would have been unable to migrate into the Errigal trap due to the 512 baffling effects of the heavily intruded Cretaceous succession (cf. Schofield et al., 2018). These 513 hydrocarbons may have instead been diverted southwards, up structural dip, towards the fault514 block trap penetrated by 12/2-1 (Dooish), located only c. $42 \mathrm{~km}$ to the south (Fig. 2). A similar 
scenario is envisaged for the prospects targeted by 164/25-1 z, 164/27-1 (Antaeus) and 154/1-2

516 (Benbecula North) in the UK Rockall, and may be a more general risk for sill-induced forced fold prospects (Schofield et al., 2018).

Trap. Borehole 5/22-1 targeted a c. $55 \mathrm{~km}^{2}$ four-way dip-closure that formed a relatively small part of a much larger (c. $224 \mathrm{~km}^{2}$ ), dome-shaped structure. This structure (a 'forced fold') formed due to the forcible emplacement of an igneous sill-complex over a c. $15 \mathrm{Myr}$ period in the earliest Paleocene to early Eocene (Magee et al., 2014). The trap was well-imaged in seismic data and was considered robust, with uncertainties in seismic velocities leading to modest uncertainties in predicted trap size, column height, and depth to top reservoir.

Although 5/22-1 was unsuccessful, similar forced fold traps have been successfully targeted in other volcanic basins. For example, the Tulipan discovery (6302/6-1), Møre Basin, offshore mid-Norway discovered gas in lower Paleocene deep-water sandstones contained in an early Eocene forced fold. In a similar manner to the structure targeted by 5/22-1, the Tulipan fold formed in response to sill emplacement in Upper Cretaceous mudstone (Schmiedel et al., 2017). Gas was also discovered in the Benbecula South prospect (154/1-1), UK Rockall. This discovery is characterised by a Paleocene deep-water sandstone reservoir contained within a well-defined four-way dip closure, representing a sill-induced forced fold (Schofield et al., 2018). The Loanan prospect (214/23-1), Faroe-Shetland Basin, offshore UK again targeted Paleocene deep-water sandstones incorporated in a sill-induced forced fold. Although the results of the well are tight, the well did not reach the lower target or its target (total) depth because of concerns related to the distribution and related pressure state of nearby sills (Mark et al., 2018).

Further afield, the Wichian Buri oil field, Phetchabun Basin, Thailand is an excellent example of a hydrocarbon accumulation associated with the emplacement of igneous rocks. In this location, emplacement of a dolerite laccolith caused forced folding of a lacustrine-fluvial clastic succession and the formation of a large trap (Schutter, 2003 and references therein).

542 Borehole Perindi-1, NW Canning Basin, offshore NW Australia targeted one of several, relatively small (3-16 $\mathrm{km}^{2}$ in areal extent; vertical closures of up to $120 \mathrm{~m}$ ) forced folds developed above Permian saucer-shaped sills (Reeckmann and Mebberson, 1984). Although the well penetrated thick (i.e. several hundred metres), high-quality ( $>25 \%$ porosity) sandstone reservoirs, capped by a thick (50-90 m) mudstone seal, the borehole was water-wet. However, the presence of oil shows indicates a working petroleum system, suggesting hydrocarbons migrated into and out of the structure. Reeckmann and Mebberson (1984) speculate Perindi-1 failed due to breaching of the seal by and loss of hydrocarbons along numerous normal faults

550 developed at the dome crest. Because they are spatially restricted to the dome crest and because 551 they die-out downwards, we infer that these faults formed due to outer-arc stretching of the fold 
during sill emplacement (cf. Hansen and Cartwright, 2006; Magee et al., 2013a; Magee et al., 2017). Sill emplacement may, therefore, drive growth of relatively large and therefore attractive forced fold-related traps, although a key risk is seal breach by outer-arc stretching-related normal faults.

Reservoir. Upper Paleocene volcaniclastic deep-water sandstones are generally clay-rich and of poor-quality (Pal. 1), likely due reflecting diagenetic degradation of the abundant volcanic grains forming the bulk of the primary depositional unit. In this sense, the poor reservoir quality is provenance related. Paleothermometric data from 5/22-1 suggest that, at some point in the past and to varying degrees, the reservoir-bearing upper Paleocene interval experienced temperatures higher than present. This heating may have enhanced and/or accelerated diagenetic degradation of the volcanic grains, yielded clay minerals, and essentially made a bad reservoir worse. We suggest this heating was caused by hot fluid circulation triggered by the emplacement of nearby intrusive bodies, such as the large (i.e. seismically imaged) sill located only c. $1.5 \mathrm{~km} \mathrm{NW}$ of 5/22-1 (Fig. 2). The presence of low-salinity inclusions suggest input of low-salinity meteoric fluids derived from deeper strata, or potentially from metamorphic fluids (Yardley \& Graham, 2002) expelled from sill intrusions.

It is also possible that the elevated temperatures could simply reflect elevated heat flow accompanying a late-Cenozoic to Palaeogene phase of rifting that affected the Faroe-Shetland Basin, an event that could have extended southwards into the NE Irish Rockall Basin (Scotchman et al., 2006). However, this model does not explain why 'normal' (i.e. consistent with that predicted by paleothermal modelling) temperatures are encountered at deeper depths, in Upper Cretaceous strata at the base of 5/22-1 (Fig. 8). It is important to note that thin intervals of good-quality reservoir do occur at the base of the succession (Pal. 2; Fig. 4), suggesting Errigal did not fail due to lack of reservoir, but possibly charge (see above). Reservoir quality does however remain a concern for the NE Irish Rockall, the broader NE Atlantic Margin, and magmatically influenced basins in general.

Rather than documenting sill- or rift-induced, elevated temperatures in upper Paleocene-to-upper Eocene samples may instead record hydrothermal venting of heated fluids and host sediment onto the seafloor via sill-fed vents. These fluids and sediment would have been sourced from the intruded Upper Cretaceous succession. This process is inferred to have led to mixing and thermal maturation of sediments vented around the Tulipan Sill, Møre Basin, offshore mid-Norway (Hafeez et al., 2017; Kjoberg et al., 2017). We see some evidence for Eocene extrusive activity, yet the products of this lie several hundred metres above the interval in which elevated paleotemperatures are observed (Figs 2 and 8; see also Fig. 11 in Magee et al., 2014). 
Seal. As we discussed above, intrusion-induced forced folds can be deformed by coeval normal

590 faults (Hansen \& Cartwright, 2006; Magee et al., 2013a; 2017), which may facilitate vertical

591 leakage of hydrocarbons from otherwise valid traps (Reeckmann \& Mebberson, 1984). Our

592 seismic data present only very limited evidence for the widespread development of seismic-

593 scale normal faults across the Errigal dome (Fig. 2). This implies outer-arc stretching-induced

594 normal faulting probably did not cause the Errigal borehole to fail. Our interpretation is

595 supported by the observation that one tentative hydrocarbon show was detected within the

596 Errigal structure, implying hydrocarbons did not migrate into and then out of the trap (cf.

597 Reeckmann \& Mebberson, 1984).

598

599 How might breakup-related magmatism influence future prospectivity in the NE Irish

$600 \quad$ Rockall Basin?

601

602 Breakup-related magmatism in the NE Irish Rockall Basin appears to have positively and 603 negatively impacted on petroleum system development in this frontier basin. For example, 604 emplacement of the igneous sill-complex drove the formation of a dome-shaped forced fold, 605 which represents a large, attractive, four-way dip closure incorporating pre-kinematic reservoirs 606 (Fig. 5A). Intrusions, if fractured, may have also facilitated hydrocarbon migration through 607 otherwise sealing, Cretaceous mudstone-dominated sequences, from deeply Palaeozoic and 608 Mesozoic source rocks to Paleocene reservoirs (e.g. Rateau et al., 2013; Mark et al., 2017). 609 However, the spatially extensive sill-complex (Fig. 2), if poorly fractured, may have had bulk 610 low permeability and thus impeded or deflected laterally the otherwise vertical migration of 611 pre-Cretaceous-sourced hydrocarbons, if generated (e.g. Thomaz Filho et al., 2008; Schofield 612 et al., 2018). Sills may also act as reservoirs, with hydrocarbons hosted in cooling-related 613 fractures. Such reservoirs can be significant, with estimated recoverable reserves thought to be 614 c. 30 million barrels (MMbbl) in the Wichian Buri oil field, Phetchabun Basin, Thailand 615 (Schutter, 2003). Although seemingly not the case in this part of the NE Irish Rockall Basin, 616 local intrusion-induced heating could have triggered maturation and gas expulsion from even 617 organically poor Cretaceous mudstones underlying the prospective Paleocene level, or 618 preserved in deep rift basins adjacent to structurally high fault blocks. Such a process is thought 619 to have triggered maturation of organically poor (i.e. $1 \% \mathrm{wt}$ organic carbon) Cretaceous 620 mudstones on the Utgard High, offshore Norway (Aarnes et al., 2015).

621 Although Errigal failed, data collected during drilling are very useful, indicating 622 reservoir-quality deep-water sandstones were at least locally deposited in the region during the 623 Late Paleocene and Eocene, and that the upper Paleocene, reservoir-bearing succession is 624 capped by a thick, post-Eocene seal (Figs 1C and 4). As such, we consider that the post- 
Cretaceous succession of the NE Irish Rockall Basin remains prospective. For example, although the intrusion-induced structural trap failed, additional prospectivity may remain in stratigraphic traps on the forced fold limbs. Intrusion-induced forced folding can drive syndepositional deformation of the seabed, causing deflection and controlling the routing of sediment gravity-currents (Smallwood and Maresh, 2002; Egbeni et al., 2014). Turbidites may thin and onlap towards, and thus be absent at, the fold crest, a stratigraphic architecture that provides the opportunity for development of stratigraphic traps. Charging such traps remains challenging due to the presence of the underlying, largely impermeable sill-complex, which may act to divert ascending hydrocarbons away from overlying traps.

\section{CONCLUSIONS}

We use 3D seismic reflection, borehole, petrographic, and paleothermometric data to document the geology of borehole 5/22-1 (the Errigal prospect), NE Irish Rockall Basin, offshore western Ireland. We conclude that:

1. Errigal tested a large $\left(55 \mathrm{~km}^{2}\right)$ four-way dip closure that formed to accommodate emplacement of a Paleocene-to-Eocene igneous sill-complex.

2. Two water-bearing turbidite sandstone-bearing intervals occur in the Upper Paleocene target interval of interest; the lowermost interval is low net-to-gross (c. 3\%) and contains thin (c. $5 \mathrm{~m}$ ), quartzose-feldspathic sandstones of good reservoir quality (up to $16 \%)$, whereas the upper interval is also of low net-to-gross $(<1 \%)$, but in contrast is dominated by thin (1-4 m), very poor-quality volcaniclastic sandstones.

3. The poor reservoir quality also likely reflects the primary composition of the reservoir, which is dominated by volcanic grains and related clays derived from an igneous rockdominated, sediment source area.

4. Paleothermometric data (FIM, VR, AFTA) provide evidence for anomalously high temperatures in the Paleocene-to-Eocene succession, suggesting that the poor reservoir quality may also reflect sill-induced heating, fluid flow, and related diagenesis (i.e. degradation of volcanic glass to pore-filling and pore throat-clogging clay minerals).

5. Errigal appeared to fail due to a lack of hydrocarbon charge; i.e. the low bulk permeability of the heavily intruded Cretaceous mudstone succession may have impeded vertical migration of sub-Cretaceous-sourced hydrocarbons into supraCretaceous reservoirs.

6. Breakup-related magmatism in the NE Irish Rockall Basin positively and negatively impacted the petroleum system development in this frontier basin. For example, sillcomplex emplacement drove formation of a large trap, whereas these low-permeability 
sill reservoirs.

7. Exploration potential remains in the NE Irish Rockall Basin, with future targets includes stratigraphically trapped, Paleocene-to-Eocene deep-water sandstones onlapping the flanks of intrusion-induced forced folds, structurally trapped, intraCretaceous deep-water sandstones incorporated within intrusion-induced forced folds, and more conventional, Mesozoic fault-block traps underlying the heavily intruded Cretaceous succession (e.g. Dooish).

\section{ACKNOWLEDGEMENTS}

The Department of Communications, Energy and Natural Resources (Petroleum Affairs Division), Ireland, is thanked for providing seismic and borehole data. Individuals and contractor companies who undertook the primary analysis of FIM, AFTA and VR data, as well as compiled the composite logs and final well reports, are also thanked; they are all mentioned by name in the reports and data contained in the various Supplementary Items.

\section{DATA AVAILABILITY STATEMENT}

The seismic and borehole datasets analysed as part of this paper are available upon request IHS Markit (releaseddata@ihs.com) (see also: https://www.dccae.gov.ie/en-ie/naturalresources/topics/Oil-Gas-Exploration-Production/data/Pages/Data.aspx).

\section{REFERENCES}

Allen, P.A. \& Allen, J.R. (2013) Basin analysis: Principles and application to petroleum play assessment. John Wiley \& Sons.

Archer, S.G., Bergman, S.C., Iliffe, J., Murphy, C.M. \& Thornton, M. (2005) Palaeogene igneous rocks reveal new insights into the geodynamic evolution and petroleum potential of the Rockall Trough, NE Atlantic Margin: Basin Research, 17, 171-201.

Aarnes, I., Planke, S., Trulsvik, M. \& Svensen, H. (2015) Contact metamorphism and thermogenic gas generation in the Vøring and Møre basins, offshore Norway, during the Paleocene-Eocene thermal maximum. Journal of the Geological Society, 172, 588-598. 
698 Berger, A., Gier, S. \& Krois, P. (2009) Porosity-preserving chlorite cements in shallow-marine

699 volcaniclastic sandstones: Evidence from Cretaceous sandstones of the Sawan gas field, 700 Pakistan. AAPG Bulletin, 93, 595-615.

Bischoff, A.P., Nicol, A. \& Beggs, M. (2017) Stratigraphy of architectural elements in a buried volcanic system and implications for hydrocarbon exploration. Interpretation, 5, SK141SK159.

Brodie, J. \& White, N.J. (1994) Sedimentary basin inversion caused by igneous underplating: Northwest European continental shelf. Geology, 22, 147-150.

Broglia, C. \& Ellis, D. (1990) Effect of alteration, formation absorption, and standoff on the response of the thermal neutron porosity log in gabbros and basalts: Examples from Deep Sea Drilling Project-Ocean Drilling Program Site. Journal of Geophysical Research, 95, 9171-9188.

Cosgrove, J.W. (2004) Hydraulic fracturing during the formation and deformation of a basin: A factor in the dewatering of low-permeability sediments. AAPG Bulletin, 85, 737-748.

Delpino, D.H. \& Bermúdez, A.M. (2009) Petroleum systems including unconventional reservoirs in intrusive igneous rocks (sills and laccoliths). The Leading Edge, 28, 804-811. Principal tectonic events in the evolution of the northwest European Atlantic margin: Petroleum Geology of Northwest Europe: Proceedings of the 5th Conference, 41-61.

Egbeni, S., McClay, K., Fu, J.J.K., \& Bruce, D. (2014). Influence of igneous sills on Paleocene turbidite deposition in the Faroe-Shetland Basin: a case study in Flett and Muckle sub-basin and its implication for hydrocarbon exploration: Geological Society, London, Special Publications, 397, 33-57.

Eide, C.H., Schofield, N., Jerram, D.A., \& Howell, J.A. (2017) Basin-scale architecture of deeply emplaced sill complexes: Jameson Land, East Greenland. Journal of the Geological Society of London, 174, 23-40. of Scotland, 4th edn. British Geological Survey, Nottingham. 
Farooqui, M.Y., Hou, H., Li, G., Machin, N., Neville, T., Pal, A., Shrivastva, C., Wang, Y., Yang, F., Yin, C. \& Zhao, J. (2009) Evaluating volcanic reservoirs. Oilfield Review, 21, 3647.

Fernandes, K. (2011) Irish sills of the North Atlantic Igneous Province: seismic imaging, observations and implications for climate change. Unpublished Ph.D Thesis. University of Dublin, Trinity College, Dublin.

Friedman, I. \& Long, W. (1984) Volcanic glasses, their origins and alteration processes. Journal of Non-Crystalline Solids, 67, 127-133.

Grove, C., Jerram, D.A., Gluyas, J.G. \& Brown, R.J. (2017) Sandstone diagenesis in sedimentlava sequences: exceptional examples of volcanically driven diagenetic compartmentalization in Dune Valley, Huab Outliers, NW Namibia: Journal of Sedimentary Research, 87, 1314-1335.

Gu, L.X., Ren, Z.W., Wu, C.Z., Zhao, M. \& Qiu, J. (2002) Subvolcanic trachyte porphyry at Oulituozi in the Liaohe basin and its mechanism for hydrocarbon reservoir formation. AAPG Bulletin, 86, 1821-1832.

Gudmundsson, A. (2011). Rock Fractures in Geological Processes. Cambridge, UK: Cambridge University Press. doi: 10.1017/CBO9780511975684.

Hafeez, A., Planke, S., Jerram, D.A., Millett, J.M., Maharjan, D. \& Prestvik, T. (2017) upper Paleocene ultramafic igneous rocks offshore mid-Norway: Reinterpretation of the Vestbrona Formation as a sill complex. Interpretation, 5, SK103-SK120.

Hansen, D.M. (2006) The morphology of intrusion-related vent structures and their implications for constraining the timing of intrusive events along the NE Atlantic margin: Journal of the Geological Society of London, 163, 789-800.

Hansen, D.M., \& Cartwright, J. (2006) The three-dimensional geometry and growth of forced folds above saucer-shaped igneous sills: Journal of Structural Geology, 28, 1520-1535.

Hansen, J., Jerram, D.A., McCaffrey, K. \& Passey, S.R. (2009) The onset of the North Atlantic Igneous Province in a rifting perspective: Geological Magazine, 146, 309-325. 
771 Haughton, P., Praeg, D., Shannon, P., Harrington, G., Higgs, K., Amy, L., Tyrrell, S. \&

772 Morrissey. T. (2005) First results from shallow stratigraphic boreholes on the eastern flank of 773 the Rockall Basin, offshore western Ireland: Geological Society, London, Petroleum Geology 774 Conference series, 6, 1077-1094.

775

Hole, M.J. \& Millett, J.M. (2016) Controls of mantle potential temperature and lithospheric thickness on magmatism in the North Atlantic Igneous Province: Journal of Petrology, 57, pp.417-436.

Holford, S.P., Schofield, N., Jackson, C.A-L., Magee, C., Green, P.F. \& Duddy, I.R. (2013). Impacts of igneous intrusions on source reservoir potential in prospective sedimentary basins along the western Australian continental margin. Proceedings of the Western Australia Basin Symposium.

Iyer, K., Schmid, D.W., Planke, S. \& Millett, J. (2017) Modelling hydrothermal venting in volcanic sedimentary basins: Impact on hydrocarbon maturation and paleoclimate. Earth and Planetary Science Letters, 467, 30-42.

Jacquemyn, C., El Desouky, H., Hunt, D., Casini, G. \& Swennen, R. (2014) Dolomitization of the Latemar platform: Fluid flow and dolomite evolution: Marine and Petroleum Geology, 55, 43-67.

Jerram, D.A. \& Widdowson, M. (2005) The anatomy of Continental Flood Basalt Provinces: geological constraints on the processes and products of flood volcanism. Lithos, 79, 385-405.

Kjoberg, S., Schmiedel, T., Planke, S., Svensen, H.H., Millett, J.M., Jerram, D.A., Galland, O., Lecomte, I., Schofield, N., Haug, Ø.T. \& Helsem, A. (2017) 3D structure and formation of hydrothermal vent complexes at the Paleocene-Eocene transition, the Møre Basin, midNorwegian margin. Interpretation, 5, SK65-SK81.

Magee, C., Briggs, F. \& Jackson C.A-L. (2013a) Lithological controls on igneous intrusioninduced ground deformation: Journal of the Geological Society of London, 170, 853-856.

Magee, C, Jackson, CA-L. \& Schofield, N. (2013b) The influence of normal fault geometry on igneous sill emplacement and morphology: Geology, 41, 407-410. 
Magee, C., Jackson, C.A-L. \& Schofield, N. (2014) Diachronous sub-volcanic intrusion along deep-water margins: Insights from the NE Irish Rockall Basin: Basin Research, 26, 85-105.

Magee, C., Jackson, C.A-L., Hardman, J.P., \& Reeve, M.T. (2017) Decoding sill emplacement and forced fold growth in the Exmouth Sub-basin, offshore northwest Australia: Implications for hydrocarbon exploration: Interpretation, 5, SK11-SK22.

Magee, C., Hoggett, M., Jackson, C.A-L., \& Jones, S. (2019) Burial-related Compaction Modifies Intrusion-induced Forced Folds: Implications for Reconciling Roof Uplift Mechanisms using Seismic Reflection Data: Frontiers in Earth Science, 7, p39.

Mark, N.J., Schofield, N., Pugliese, S., Watson, D., Holford, S., Muirhead, D., Brown, R. \& Healy, D. (2018) Igneous intrusions in the Faroe Shetland basin and their implications for hydrocarbon exploration; new insights from well and seismic data: Marine and Petroleum Geology, 92, 733-753.

McClay, K., Scarselli, N. \& Jitmahantakul, S. (2013) Igneous intrusions in the Carnarvon Basin, NW Shelf, Australia: The sedimentary basins of Western Australia IV: Proceedings of the Petroleum Exploration Society of Australia Symposium, Petroleum Exploration Society of Australia, 1-20.

McKinley, J.M., Worden, R.H. \& Ruffell, A.H. (2003) Smectite in Sandstones: A Review of the Controls on Occurrence and Behaviour During Diagenesis: Clay Mineral Cements in Sandstones, edited, pp. 109-128, Blackwell Publishing Ltd.

Millett, J.M., Wilkins, A.D., Campbell, E., Hole, M.J., Taylor, R.A., Healy, D., Jerram, D.A., Jolley, D.W., Planke, S., Archer, S.G. \& Blischke, A. (2016) The geology of offshore drilling through basalt sequences: Understanding operational complications to improve efficiency. Marine and Petroleum Geology, 77, 1177-1192.

Muirhead, D.K., Bowden, S.A., Parnell, J. \& Schofield, N. (2017) Source rock maturation owing to igneous intrusion in rifted margin petroleum systems. Journal of the Geological Society, 174, 979-987.

Naylor, D. \& Shannon, P.M. (2005) The structural framework of the Irish Atlantic Margin. In Petroleum geology: N.W. Europe and Global Perspectives, Proceedings of the 6th Petroleum Geology Conference., 1009-1021. 
845 Primmer, T.J., Cade, C.A., Evans, J., Gluyas, J.G., Hopkins, M.S., Oxtoby, N.H., Smalley, P.C.,

846 Warren, E.A. \& Worden, R.H. (1997) Global patterns in sandstone diagenesis: their application

847 to reservoir quality prediction for petroleum exploration: Reservoir quality prediction in

848 sandstones and carbonates, AAPG Memoir, 69, 61-77.

849

850 Rateau, R., Schofield, N. \& Smith, M. (2013) The potential role of igneous intrusions on

851 hydrocarbon migration, West of Shetland: Petroleum Geoscience, 19, 259-272,

852

853 Reeckman, S.A. \& Mebberson, A.J. (1984) Igneous intrusions in the north-west Canning Basin

854 and their impact on oil exploration: Proceedings of the Canning Basin Symposium, Perth:

855 Petroleum Exploration Society of Australia Ltd., 45-52.

856

Rodriguez Monreal, F., Villar, H.J., Baudino, R., Delpino, D. \& Zencich, S. (2009) Modeling an atypical petroleum system: a case study of hydrocarbon generation, migration and accumulation related to igneous intrusions in the Neuquén Basin, Argentina: Marine and Petroleum Geology, 26, 590-605.

861

862 Rohrman, M. (2007) Prospectivity of volcanic basins: trap delineation and acreage de-risking: AAPG Bulletin, 91, 915-939.

Rohrman, M. (2015). Delineating the Exmouth mantle plume (NW Australia) from denudation and magmatic addition estimates: Lithosphere, 7, 589-600.

Schmiedel, T., Kjoberg, S., Planke, S., Magee, C., Galland, O., Schofield, N., Jackson, C.A.L. and Jerram, D.A., 2017. Mechanisms of overburden deformation associated with the emplacement of the Tulipan sill, mid-Norwegian margin: Interpretation 5, SK23-SK38.

Schofield, N., Holford, S., Millett, J., Brown, D., Jolley, D., Passey, S.R., Muirhead, D., Grove, C., Magee, C., Murray, J. \& Hole, M. (2017) Regional magma plumbing and emplacement mechanisms of the Faroe-Shetland Sill Complex: implications for magma transport and petroleum systems within sedimentary basins: Basin Research, 29, 41-63. 
880 Senger, K., Buckley, S.J., Chevallier, L., Fagereng, Å., Galland, O., Kurz, T.H., Ogata, K., 881 Planke, S. \& Tveranger, J. (2015) Fracturing of doleritic intrusions and associated contact 882 zones: Implications for fluid flow in volcanic basins. Journal of African Earth Sciences, 102, 70-85.

Smallwood, J.R. \& Maresh, J. (2002) The properties, morphology and distribution of igneous sills: Modelling, borehole data and 3D seismic from the Faroe-Shetland area: Geological Society, London, Special Publications, 197, 271-306.

Svensen, H., Planke, S., Malthe-Sørenssen, A., Jamtveit, B., Myklebust, R., Eidem, T.R. \& Rey, S.S. (2004) Release of methane from a volcanic basin as a mechanism for initial Eocene global warming. Nature, 429, p.542.

Thomaz Filho, A., Mizusaki, A.M.P. \& Antonioli, L. (2008) Magmatism and petroleum exploration in the Brazilian Paleozoic basins. Marine and Petroleum Geology, 25, 143-151.

Thomson, K. \& Hutton, D. (2004) Geometry and growth of sill complexes: insights using 3D seismic from the North Rockall Trough. Bulletin of Volcanology, 66, 364-375.

Tuitt, A., Underhill, J.R., Ritchie, J.D., Johnson, H. \& Hitchen, K. (2010) Timing, controls and consequences of compression in the Rockall-Faroe area of the NE Atlantic Margin", Petroleum Geology: From Mature Basins to New Frontiers - Proceedings of the 7th Petroleum Geology Conference, B. A. Vining, S. C. Pickering.

Tyrrell, S., Souders, A.K., Haughton, P.D., Daly, J.S. \& Shannon, P.M. (2010) Sedimentology, sandstone provenance and palaeodrainage on the eastern Rockall Basin margin: evidence from the $\mathrm{Pb}$ isotopic composition of detrital K-feldspar: Geological Society, London, Petroleum Geology Conference series, 7, 937-952.

Wang, K., Chen, M., Ma, Y., Liu, K., Liu, L., Li, X. \& Hu, W. (2012) Numerical modelling of the hydrocarbon generation of Tertiary source rocks intruded by doleritic sills in the Zhanhua depression, Bohai Bay Basin, China. Basin Research, 24, 234-247.

Wu, C., Gu, L., Zhang, Z., Ren, Z., Chen, Z. \& Li, W. (2006) Formation mechanisms of hydrocarbon reservoirs associated with volcanic and subvolcanic intrusive rocks: Examples in Mesozoic-Cenozoic basins of eastern China. AAPG Bulletin, 90, 137-147. 
918 sills of the Rio Grande Valley, northern Neuquén Basin, Argentina: AAPG Bulletin, 96, 1253 9191277.

921 Yardley, B.W.D. \& Graham, J.T. (2002) The origins of salinity in metamorphic fluids: 922 Geofluids, 2, 249-256.

\section{Figure captions}

Fig. 1. (A) Location map of the Irish Rockall Basin (IRB) highlighting the distribution of igneous intrusions and extrusions (offshore central complexes, red circles; onshore central complexes and lavas, green ornament; offshore lavas, light grey ornament; seaward-dipping reflectors, dark grey ornament; hydrothermal vents, black triangles) associated with the North Atlantic Igneous Province (modified from Emeleus \& Bell, 2005; Hansen, 2006). The bathymetric contours (grey lines; spacing=500 m) delineate the boundaries of the Northern Rockall Basin (NRB), Porcupine (PB), Hatton (HB), Faroe-Shetland (FSB), Møre (MB) and Vøring (VB) basins, as well as the Hatton (H) and Rockall (R) banks, and the Vøring Plateau (VP). The Anton-Dohrn Lineament Complex (ADLC) is also labelled. (B) Bathymetry map of the Irish Rockall Basin, illustrating the location of the 3D seismic reflection survey and positions of boreholes 12/2-1 (Dooish) and 5/22-1 (Errigal). Note the proximity of the study area to the Hebridean Terrace Igneous Complex (HTIC). (C) Simplified chronostratigraphic column for the interval of interest depicting the key lithologies identified in boreholes 12/2-1 and 5/22-1 (N.B. only for the depth interval $2250 \mathrm{~m}$ to borehole total depth or 'TD'), and our seismic-stratigraphic framework (which extends from seabed down to the Permian). $J=$ top Jurassic; $\mathrm{KI}=$ intra-Lower Cretaceous; $\mathrm{KC}=$ top-Coniacian; $\mathrm{K}=$ top Cretaceous; $\mathrm{P}=$ top Paleocene; E=top Lower Eocene (based on lithostratigraphic and chronostratigraphic data provided in Supplementary items 1, 2 and 5; see also Magee et al., 2014). Proven or speculated petroleum system elements are shown; $\mathrm{So}=$ source rock; $\mathrm{R}=$ reservoir rock; $\mathrm{Se}=$ seal rock.

Fig. 2. (A) Seismic section and (B) geoseismic section intersecting 12/2-1 (Dooish) and 5/221 (Errigal), illustrating the overall geometry of the NE Irish Rockall Basin, and the seismic expression, geometry and distribution of igneous sills. Note the low-relief dome penetrated by 5/22-1 and its spatial relationship to the underlying igneous sill-complex, which is largely hosted in Upper Cretaceous rocks. Note also the lavas and a potential magmatic vent, both located in Eocene strata (see Fig. 11 in Magee et al. 2014). Syn-rift III (Lower to Upper

952 Cretaceous) has a post-rift appearance in this section, onlapping onto the synrift I/II-cored fault 953 block drilled by 12/2-1; however, in other sections, this package thickens towards rift-related 
normal faults and has a synrift character. See Fig. 1B for location. Vertical exaggeration (VE) $=c . \mathrm{x} 4$. Legend for colours in (B) is shown in Fig. 1C.

Fig. 3. Interpreted seismic sections (left) and 3D time-structure maps (right) showing the geometry of igneous sills in the NE Irish Rockall Basin. Numbers refer to sills described by Magee et al. (2014); see Fig. 6c and d in Magee et al. (2014) for location of sills. White lines on 3D time-structure maps show positions of the seismic sections.

Fig. 4. Simplified stratigraphic correlation between 12/2-1 (Dooish) and 5/22-1 (Errigal) showing the principal lithologies encountered in the Upper Cretaceous to Lower Eocene succession. Lithological interpretation is based largely on cuttings and sparse sidewall cores. Pal. 1=informally defined stratigraphic unit 'Paleocene 1'; Pal. 2= informally defined stratigraphic unit 'Paleocene 2'; see text for discussion and Supplementary Material Item 1 and 5 for additional details. Large coloured circles represent diagenetic features and small whitegrey circles represent the main petrographic rock types; see text for full discussion. Note that two arkosic-lithic arenite samples (white) and two lithic arenite samples (light-grey) are closely spaced and are thus represented by only one dot, hence the apparent sample number mismatch with the QFL plot in Fig. 6. For location of boreholes see Figs 1B and 2.

Fig. 5. (A) Top Paleocene time-structure map (see Fig. 1C). Contour spacing $=50 \mathrm{~m}$. Note the location of 5/22-1 on the crest of a broad, low-relief dome. (B) Lower Eocene isochron (timethickness) map (see Fig. 1C). Note thinning of this succession across the broad, low-relief dome defined at top Paleocene level (see (A)). (C) Map depicting the geometries and stacking pattern of the 82, largely Upper Cretaceous-hosted igneous sills (see Figs 2 and 3). Note that sill stacking density (and inferred bulk sill thickness) is greatest immediately below the broad, lowrelief dome identified at top Paleocene level (see (A)).

Fig. 6. (A) QFL (quartz-feldspar-lithics) derived from petrographic analysis of the Paleocene succession in 5/22-1 (Errigal). Location of samples is shown in Fig. 4. Raw data is shown in Supplementary Item 1. (B) Thin-section micrograph from sidewall core \#38 (3587 m; upper Paleocene). Note the dominance of volcaniclastic rock fragments (including volcanic glass; $\mathrm{G}$ ), the presence of subordinate quartz $(\mathrm{Q})$ and feldspar $(\mathrm{F})$, and the pore-filling analcite cement (a). (C) Thin-section micrograph from sidewall core \#18 (3916 m; upper Paleocene). Note the dominance of detrital quartz $(\mathrm{Q})$ and feldspar $(\mathrm{F})$; volcaniclastic rock fragments $\mathrm{v}(\mathrm{G})$ are rare. $\mathrm{e}=$ blue staining used to highlight pore space. See Supplementary Material Item 1 for additional petrographic data. 
991 Fig. 7. Plot showing fluid inclusion microthermometry data from 5/22-1 (Errigal). Note the 992 overall low homogenisation temperatures $\left(<90^{\circ}\right)$ for all samples. See text for full discussion.

993 See Supplementary Material Item 3 for additional fluid inclusion-derived, microthermometric 994 data.

Fig. 8. Plot of VR vs. depth for 5/22-1 (Errigal). The degree of confidence in each vitrinite reflectance value was provided by Enterprise Ireland, ranging from A (high) to E (low) (see Supplementary Material 4 for discussion). No additional information was provided on what constituted a high vs. low confidence value. Right-hand column shows simplified lithology (see

1000 Fig. 4). Error bars=one standard deviation; note that errors bars were not provided for two of 1001 the 'confidence level E' data points (red). See Supplementary Material Item 3 for additional 1002 details on paleothermal modelling parameters.

Fig. 9. (A) AFTA data (left) and present temperature (right) plotted against sample depth (and stratigraphic age). The dashed black line on the left-hand panel indicates the stratigraphic age of the penetrated succession. Note that in all cases, fission track ages are significantly higher than the respective stratigraphic ages, suggesting: (i) these apatites contain a large proportion of fission tracks formed prior to deposition of the host sediments; and (ii) post-depositional heating effects were modest. (B) Preferred thermal history interpretation of AFTA and VR data from 5/22-1 (Errigal). The origin of the cooling event at ca. $10 \mathrm{Ma}$ is unknown, but could relate to regional basin uplift, the cause of which is also unknown. All data and interpretations are from Supplementary Item 4.

Table 1. Vitrinite reflectance (VR) and paleotemperature analysis interpretation of VR data from 5/22-1 (Errigal). 'Measured VR' values are mean reflectance values for each sample. Estimates of maximum paleotemperature were determined using an assumed heating rates of $1^{\circ} \mathrm{C} / \mathrm{Ma}$ and a cooling rate of $10^{\circ} \mathrm{C} / \mathrm{Ma}$.

Table 2. Apatite Fission Track Analysis (AFTA) data for 5/22-1 (Errigal). Note that present temperature estimates are based on an assumed mean seabed temperature of $5^{\circ} \mathrm{C}$ and a presentday thermal gradient of $26.5^{\circ} \mathrm{C} / \mathrm{km}$. Thermal history interpretation of AFTA data is based on an assumed heating rate of $1{ }^{\circ} \mathrm{C} / \mathrm{Ma}$ and a cooling rate of $10^{\circ} \mathrm{C} / \mathrm{Ma}$. Quoted ranges for paleotemperature and onset of cooling correspond to $\pm 95 \%$ confidence limits. See Supplementary Item 3 for additional details on paleothermal modelling parameters and uncertainties. 
1027 Supplementary Item 1. Well IRE 5/22-1 "Errigal Deepwater Exploration” Final Well Report.

1028 Volume 1: Geological and Petrophysical Evaluation. Republic of Ireland Continental Shelf Oil

1029 Well Records. Prepared by Toby Lenehan. Published in 2001. Report provided by the

1030 Petroleum Affairs Division (PAD). Curated by IHS Energy. Available for download from:

1031 https://www.dccae.gov.ie/en-ie/natural-resources/topics/Oil-Gas-Exploration-

1032 Production/data/Pages/Data.aspx.

Supplementary Item 2. Wellsite litholog for ERRIGAL IRE 5/22-1. Wellsite geologists:

1035 James Hollands and Alastair Flood. Provided by the Petroleum Affairs Division (PAD).

1036 Available for download from: https://www.dccae.gov.ie/en-ie/natural-resources/topics/Oil-

1037 Gas-Exploration-Production/data/Pages/Data.aspx.

Supplementary Item 3. Evidence for the conditions of cementation and petroleum emplacement from fluid inclusions, Eastern Rockall Basin, Eire. Republic of Ireland Continental Shelf Oil Well Records. Prepared by Fluid Inclusion Analyses (FIA). Report provided by the Petroleum Affairs Division (PAD). Curated by IHS Energy. Available for download from: https://www.dccae.gov.ie/en-ie/natural-resources/topics/Oil-Gas-ExplorationProduction/data/Pages/Data.aspx.

Supplementary Item 4. Thermal history reconstruction in Errigal deepwater exploration well 5/22-1, using AFTA and vitrinite reflectance. Republic of Ireland Continental Shelf Oil Well Records. Published in 2001. Geotrack report \#807. Prepared by P.F.Green (Geotrack). Report provided by the Petroleum Affairs Division (PAD). Curated by IHS Energy. Available for download from: https://www.dccae.gov.ie/en-ie/natural-resources/topics/Oil-Gas-ExplorationProduction/data/Pages/Data.aspx.

Supplementary Item 5. IRE 12/2-1 Dooish composite log. Wellsite geologists: Peter Geerlings and Nick O'Neill. Log compiled by Peter Geerlings and Toby Lenehan. Report provided by the Petroleum Affairs

Division (PAD)

Available for download from: https:/www.dccae.gov.ie/en-ie/natural-resources/topics/Oil-Gas-ExplorationProduction/data/Pages/Data.aspx. 
Fig. 1



(B)

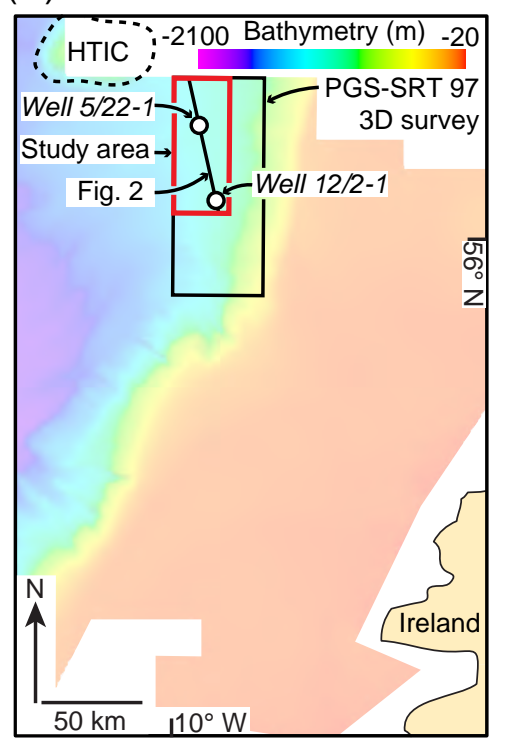

(C)

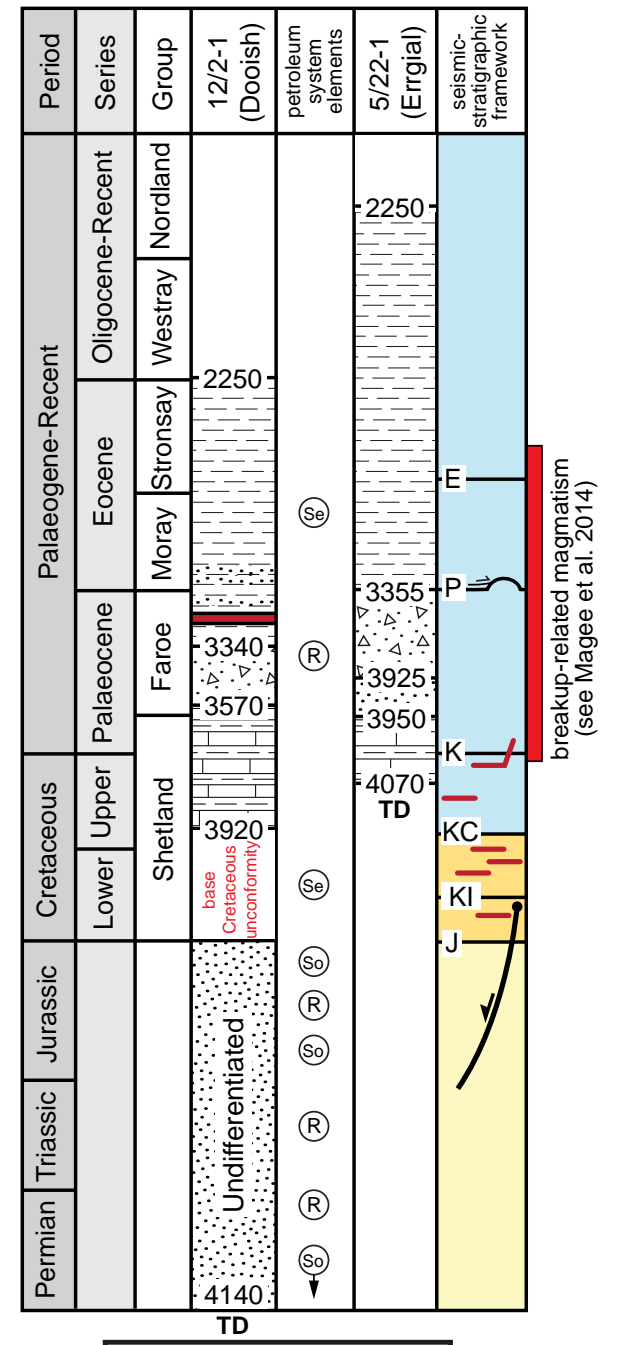

Key

Normal fault

$\frown$ Forced fold

- Onlap

- Sill

$\because \quad$ Sandstone

Volcaniclastics Marl Claystone Post-rift

Syn-rift III Syn-rift I and II 
Fig. 2

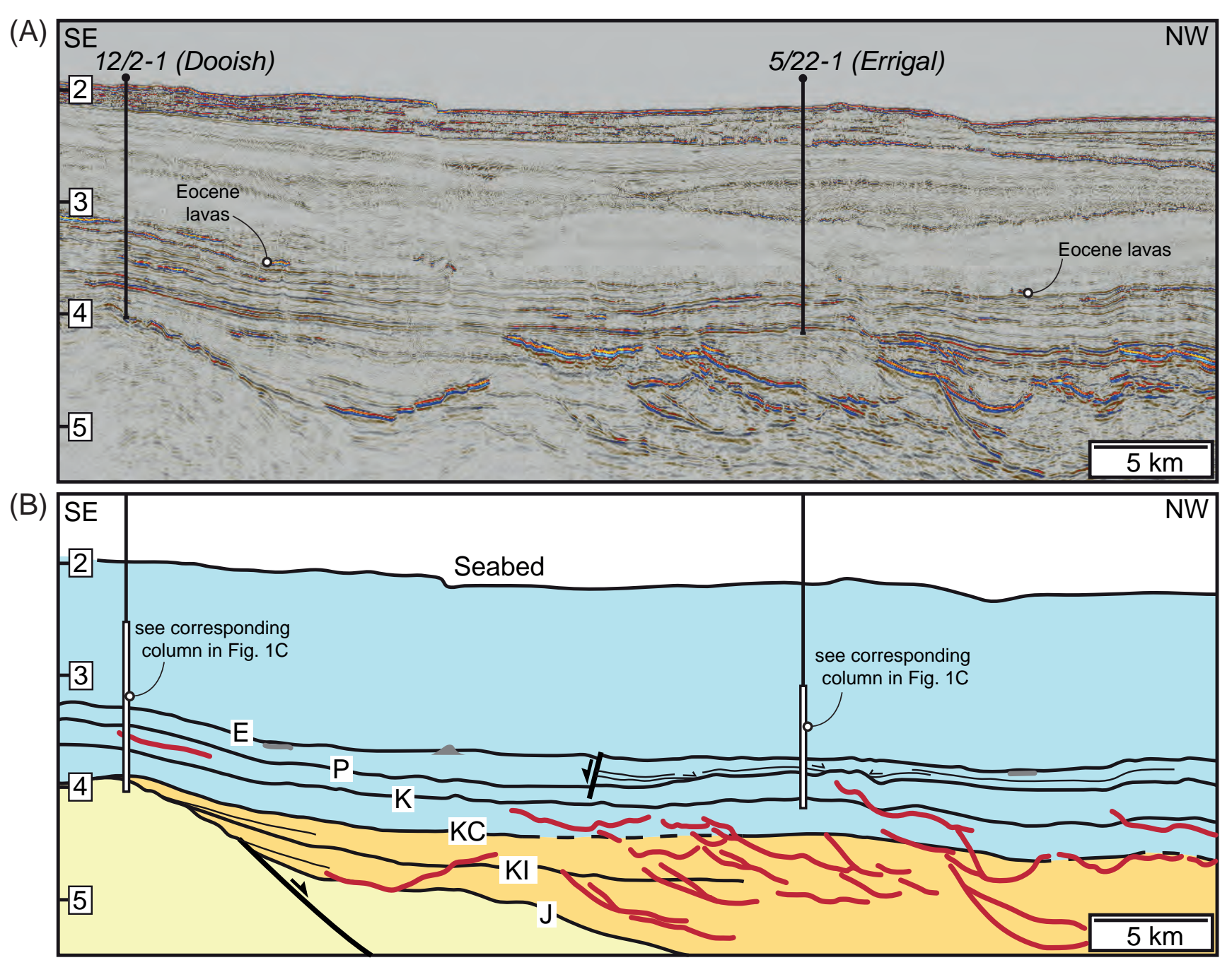


Fig. 3

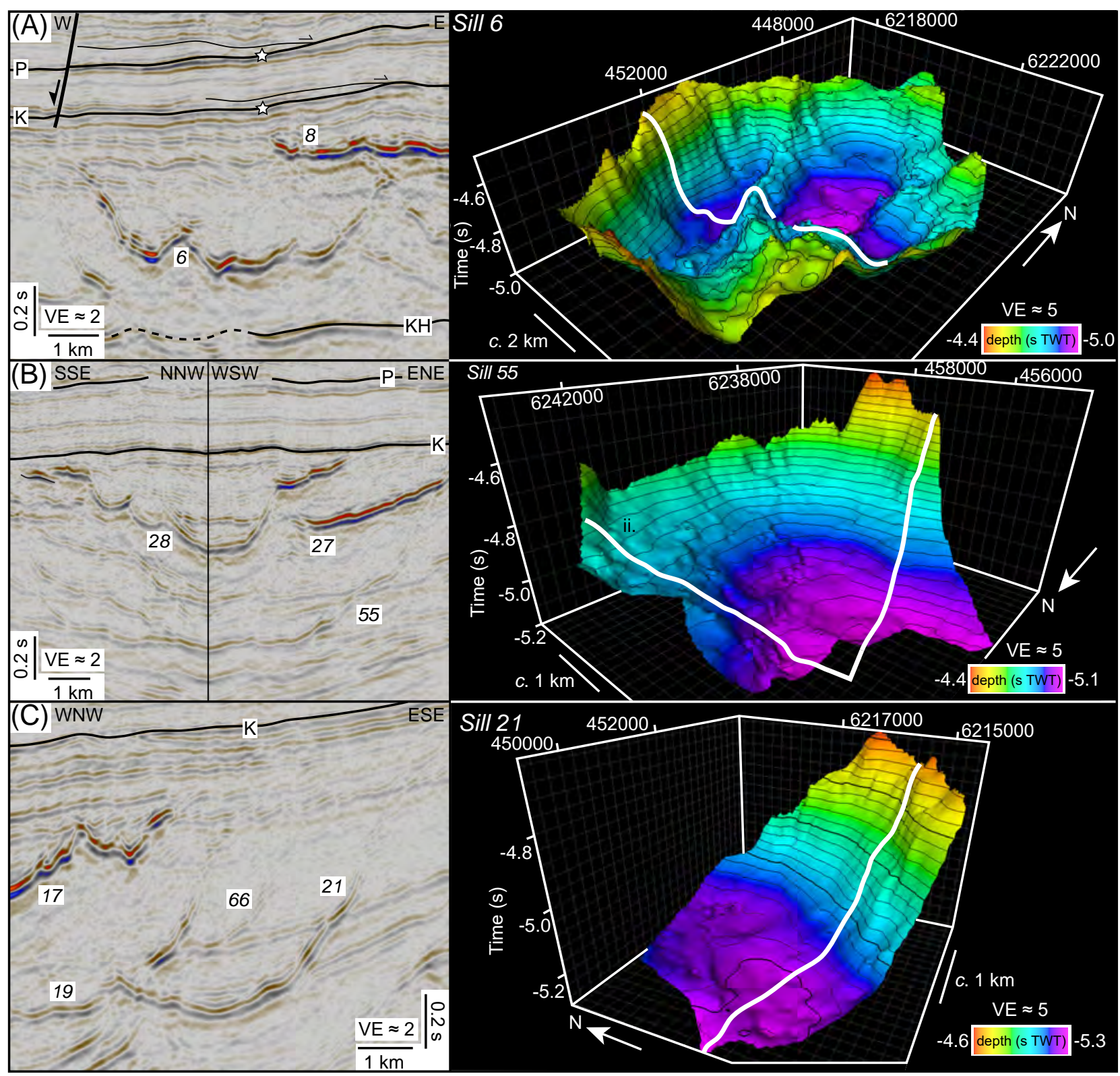


Fig. 4

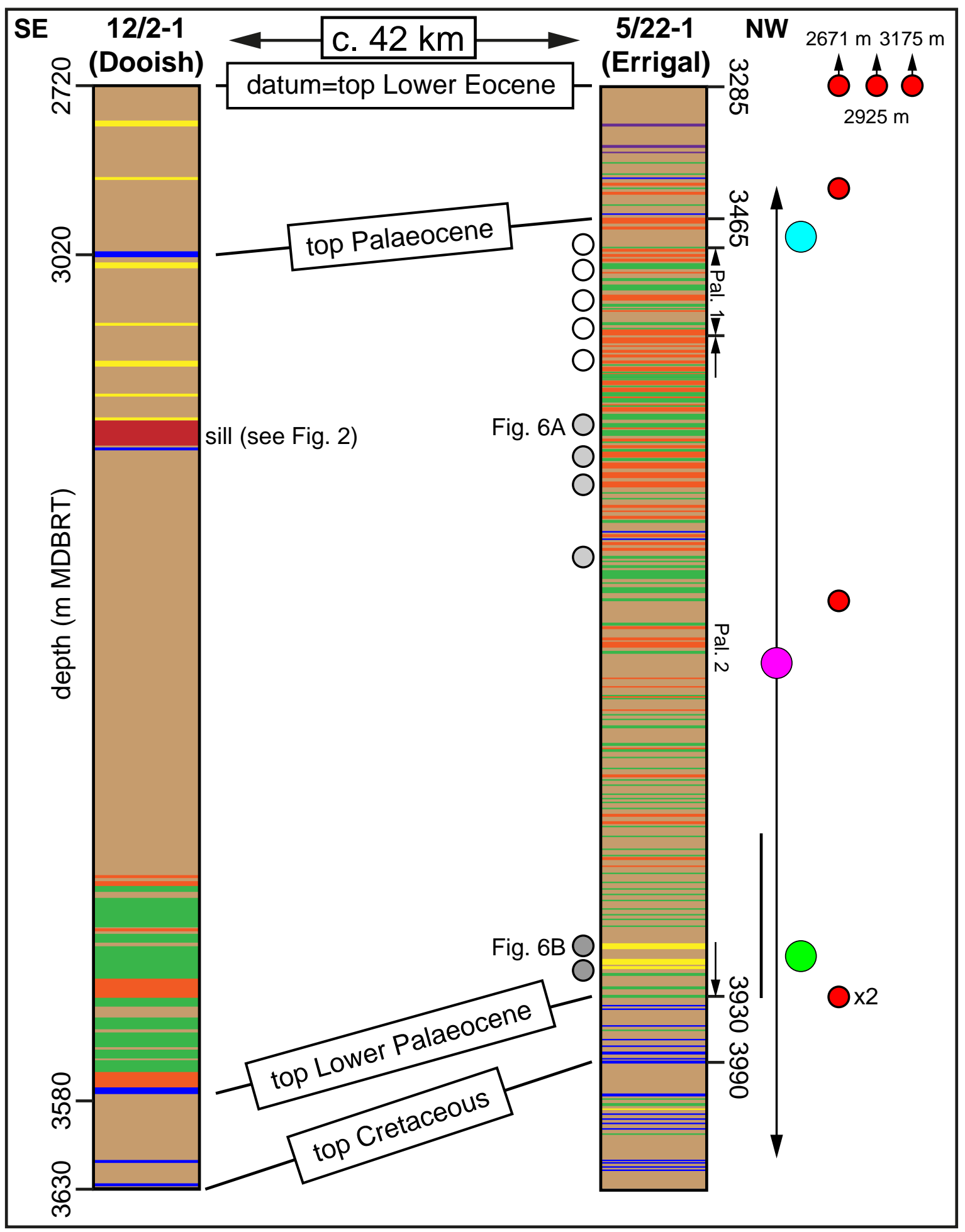

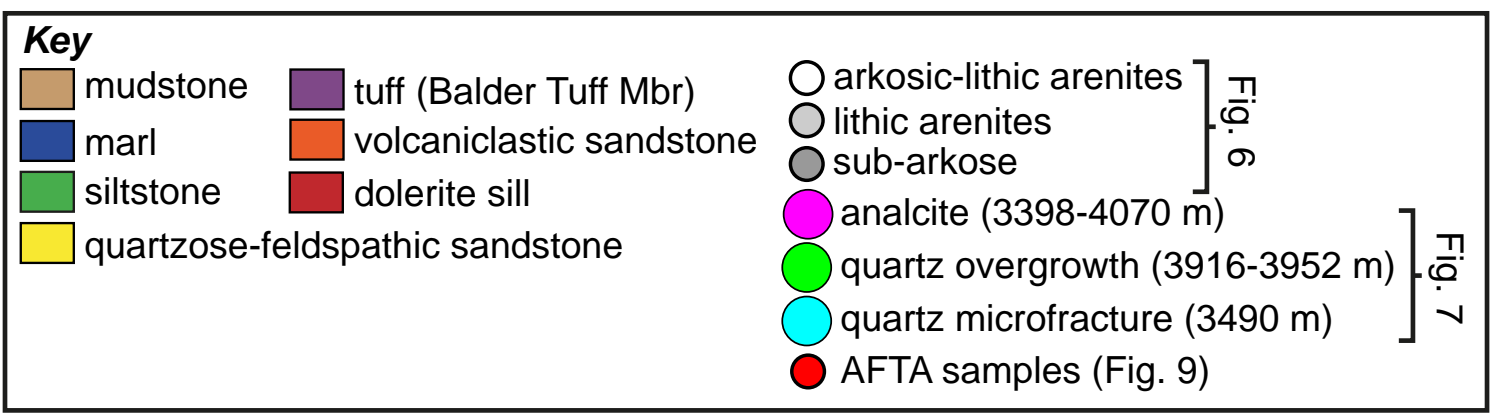


Fig. 5
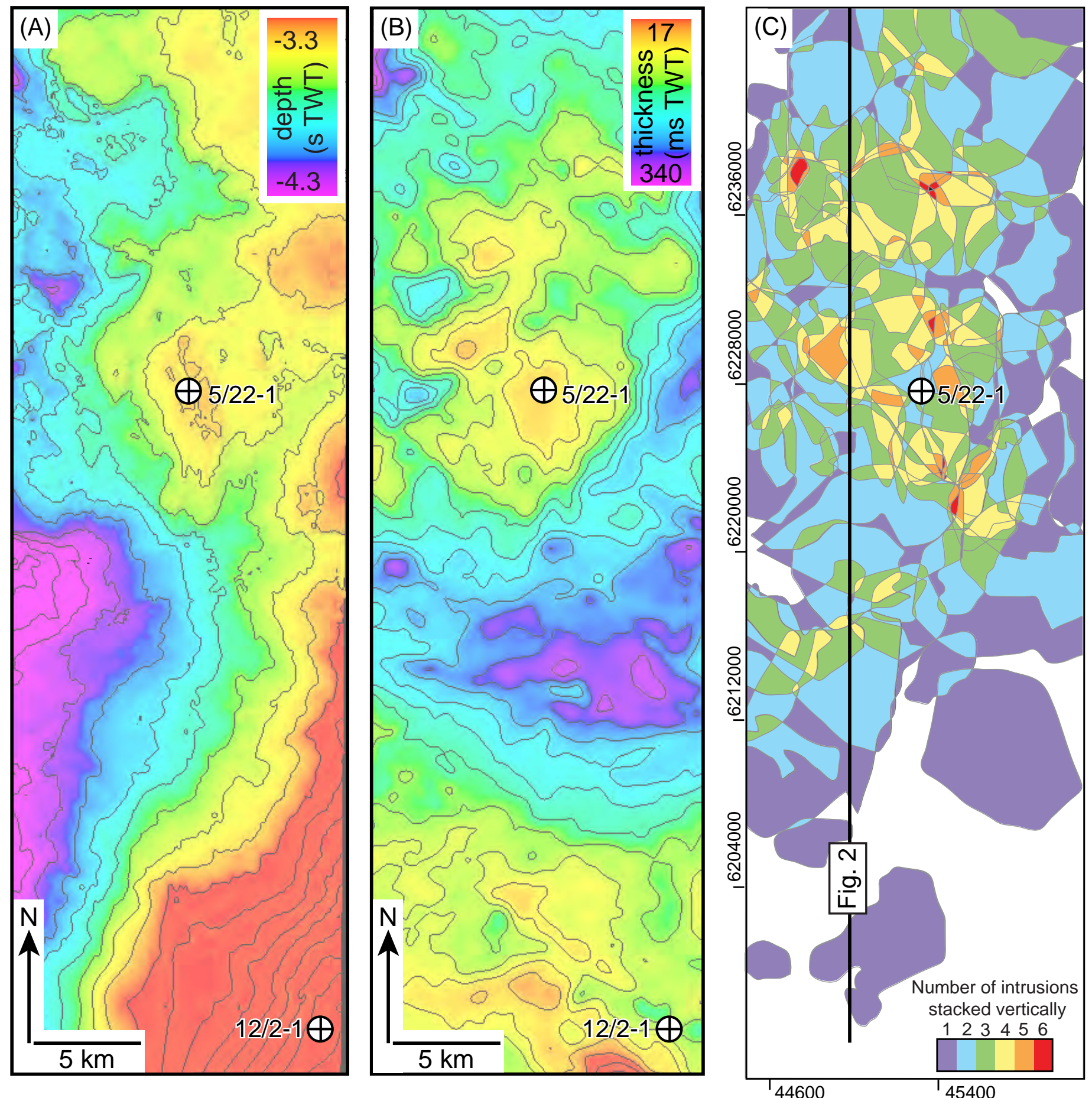
Fig. 6
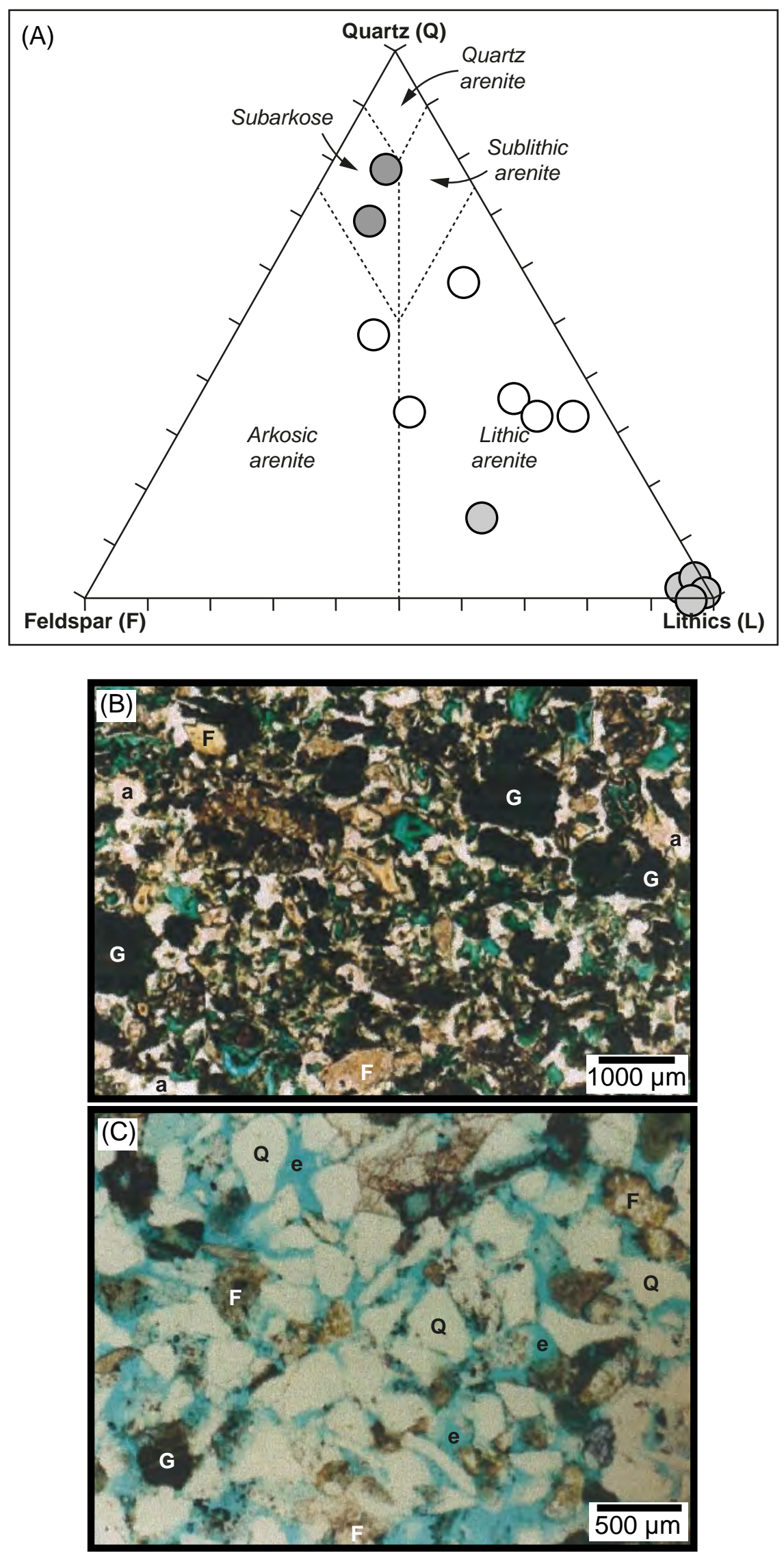
Fig. 7

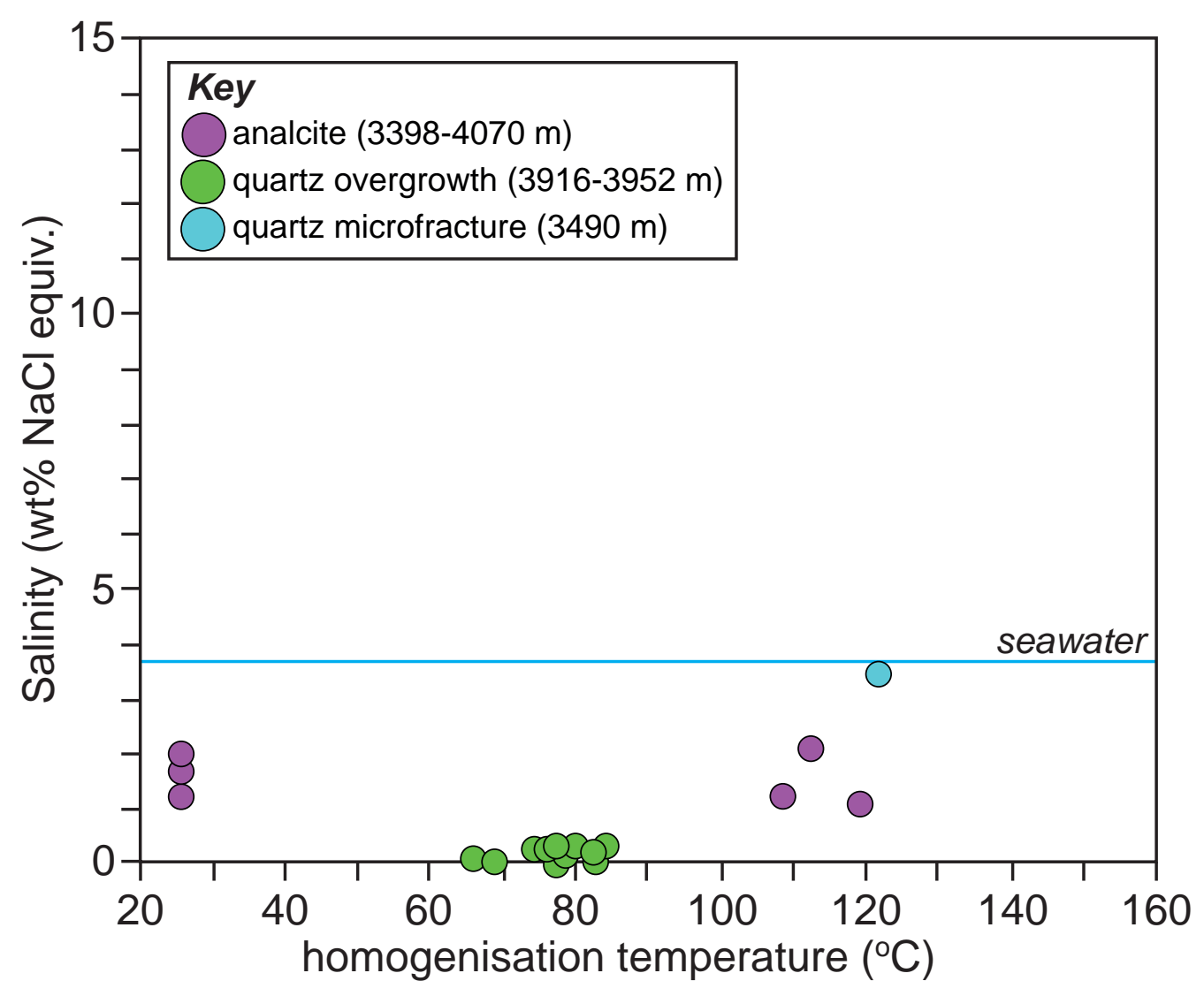


Fig. 8

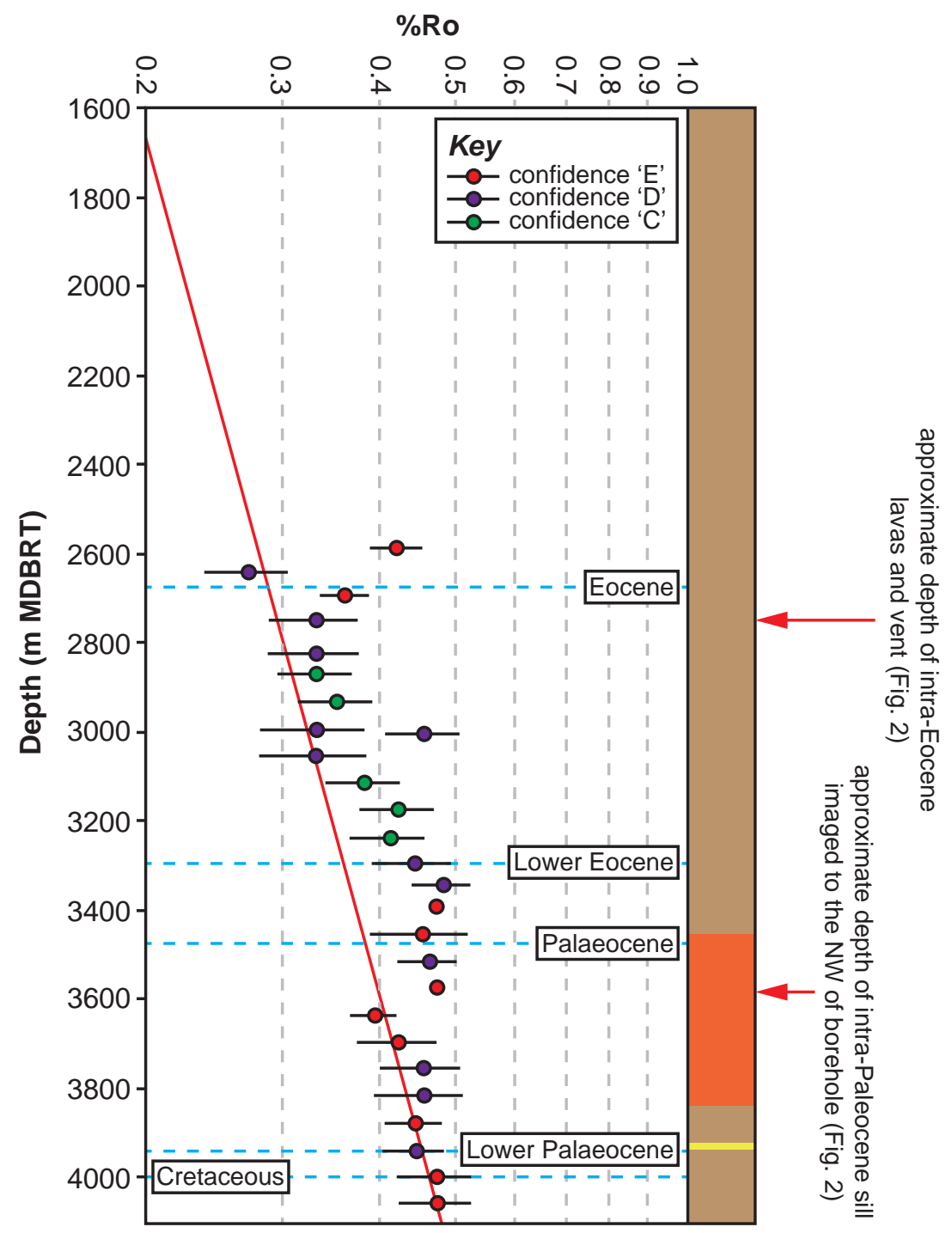


Fig. 9
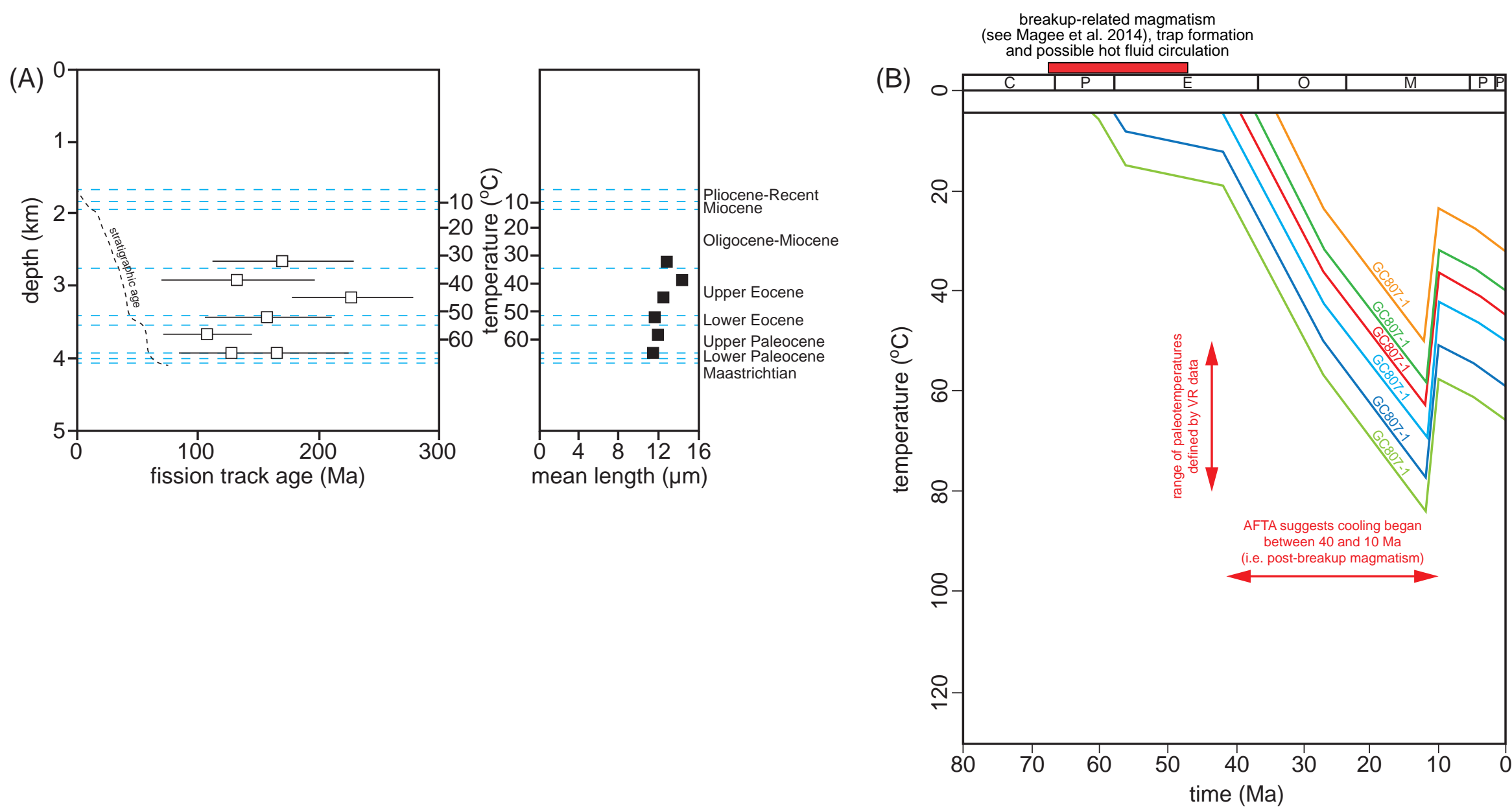
Table 1

\begin{tabular}{|c|c|c|c|c|c|}
\hline Average Depth (m) & Present temperature $\left({ }^{\circ} \mathrm{C}\right)$ & Stratigraphic age (Ma) & Measured VR (\%) & Number of readings & Maximum paleotemperature $\left({ }^{\circ} \mathrm{C}\right)$ \\
\hline 2589 & 29 & $35-16$ & 0.42 & 3 & 70 \\
\hline 2643 & 31 & $35-16$ & 0.27 & 7 & $<50$ \\
\hline 2697 & 32 & $35-16$ & 0.36 & 4 & 59 \\
\hline 2751 & 34 & $35-16$ & 0.33 & 8 & 50 \\
\hline 2823 & 36 & $42-35$ & 0.33 & 20 & 50 \\
\hline 2871 & 37 & $42-35$ & 0.33 & 20 & 50 \\
\hline 2931 & 38 & $42-35$ & 0.35 & 20 & 56 \\
\hline 2991 & 40 & $42-35$ & 0.33 & 20 & 50 \\
\hline 3051 & 42 & $42-35$ & 0.33 & 20 & 50 \\
\hline 3111 & 43 & $42-35$ & 0.38 & 20 & 63 \\
\hline 3171 & 45 & $42-35$ & 0.42 & 20 & 70 \\
\hline 3231 & 46 & $42-35$ & 0.41 & 20 & 69 \\
\hline 3291 & 48 & $42-35$ & 0.44 & 20 & 74 \\
\hline 3339 & 49 & $42-35$ & 0.48 & 20 & 80 \\
\hline 3387 & 50 & $42-35$ & 0.47 & 1 & 79 \\
\hline 3450 & 52 & $56-42$ & 0.45 & 13 & 76 \\
\hline 3510 & 54 & $56-42$ & 0.46 & 14 & 78 \\
\hline 3570 & 55 & $56-42$ & 0.47 & 1 & 79 \\
\hline 3630 & 57 & $60-56$ & 0.39 & 3 & 65 \\
\hline 3690 & 59 & $60-56$ & 0.42 & 4 & 70 \\
\hline 3750 & 60 & $60-56$ & 0.45 & 13 & 76 \\
\hline 3810 & 62 & $60-56$ & 0.45 & 17 & 76 \\
\hline 3870 & 63 & $60-56$ & 0.44 & 4 & 74 \\
\hline 3930 & 65 & $65-60$ & 0.44 & 11 & 74 \\
\hline 3990 & 66 & $65-60$ & 0.47 & 3 & 79 \\
\hline 4050 & 68 & $74-65$ & 0.47 & 2 & 79 \\
\hline
\end{tabular}


Table 2

\begin{tabular}{|c|c|c|c||c||c|}
\hline Sample number & Mean depth (mkb) & Stratigraphic age (Ma) & Present temperature $\left({ }^{\circ} \mathbf{C}\right)$ & Maximum paleotemperature $\left({ }^{\circ} \mathbf{C}\right)$ & Onset of cooling (Ma) \\
\hline GC807-1 & 2671 & $42-16$ & 31 & $<100$ \\
\hline GC807-2 & 2925 & $42-35$ & 38 & $<110$ \\
\hline GC807-3 & 3175 & $42-35$ & 45 & $60-90$ \\
\hline GC807-4 & 3438 & $60-35$ & 52 & $80-100$ \\
\hline GC807-5 & 3688 & $60-56$ & 58 & $75-90$ & post-depositional \\
\hline GC807-6 & 3936 & $74-56$ & 65 & $75-100$ \\
\hline GC807-7 & 3936 & $74-56$ & 65 & $80-100$ & post-depositional \\
\hline & & & & $40-0$ \\
\hline
\end{tabular}

